NBER WORKING PAPER SERIES

\title{
FERTILITY, FEMALE LABOR FORCE PARTICIPATION, AND THE DEMOGRAPHIC DIVIDEND
}

\author{
David E. Bloom \\ David Canning \\ Günther Fink \\ Jocelyn E. Finlay \\ Working Paper 13583 \\ http://www.nber.org/papers/w13583
}

\author{
NATIONAL BUREAU OF ECONOMIC RESEARCH \\ 1050 Massachusetts Avenue \\ Cambridge, MA 02138 \\ November 2007
}

The authors are grateful to David Weil and the participants of the Workshop on Population Aging and Economic Growth for their valuable comments. We extend our thanks to Mansour Farahani for compiling the family planning data. Support for this research was provided by grant number 5 P30 AG024409 from the National Institute on Aging, National Institutes of Health, and by grants from the William and Flora Hewlett Foundation and the John D. and Catherine T. MacArthur Foundation. The views expressed herein are those of the author(s) and do not necessarily reflect the views of the National Bureau of Economic Research.

(C) 2007 by David E. Bloom, David Canning, Günther Fink, and Jocelyn E. Finlay. All rights reserved. Short sections of text, not to exceed two paragraphs, may be quoted without explicit permission provided that full credit, including (C) notice, is given to the source. 
Fertility, Female Labor Force Participation, and the Demographic Dividend

David E. Bloom, David Canning, Günther Fink, and Jocelyn E. Finlay

NBER Working Paper No. 13583

November 2007

JEL No. J01,J1,J13,J21

\section{ABSTRACT}

We estimate the effect of fertility on female labor force participation in a cross-country panel data set using abortion legislation as an instrument for fertility. We find a large negative effect of the fertility rate on female labor force participation. The direct effect is concentrated among those aged 20-39, but we find that cohort participation is persistent over time giving an effect among older women. We present a simulation model of the effect of fertility reduction on income per capita, taking into account these changes in female labor force participation as well as population numbers and age structure.

David E. Bloom

Harvard University

Department of Population

and International Health

Building I

655 Huntington Ave.

Boston, MA 02115

and NBER

dbloom@hsph.harvard.edu

David Canning

Harvard School of Public Health

SPH Population International Health

SPH1 1211

677 Huntington Avenue

Boston, MA 02115

dcanning@hsph.harvard.edu
Günther Fink

Harvard School of Public Health

Harvard University

gfink@hsph.harvard.edu

Jocelyn E. Finlay

Harvard School of Public Health

Harvard University

jfinlay@hsph.harvard.edu 


\section{Introduction}

During the demographic transition, sharp declines in fertility lead to large changes in a population's age structure. Smaller birth cohorts decrease youth dependency ratios and mechanically increase output per capita if output per worker and the labor force participation rate of the working-age population remain unchanged. This generates the demographic dividend, which has been shown to be important in explaining crosscountry variation in the growth of per capita income (Bloom and Freeman 1987; Brander and Dowrick 1994; Kelley and Schmidt 1995; Bloom and Williamson 1998; Bloom, Canning et al. 2003).

In addition to creating these age structure effects, demographic change may also incite behavioral changes. Longer life spans may affect retirement and savings decisions (Bloom, Canning et al. 2007), while fertility reduction can affect female labor market participation. We use a panel of 97 countries over the period 1960 to 2000 to examine the effect of fertility on female labor force participation by five-year age groups.

Studies of the impact of fertility are complicated by the endogeneity of fertility and the resulting difficulty in identifying the direction of causality (Browning 1992). In microeconomic studies it is common to use twins, or the sex composition of previous births, as factors that produce exogenous variation in fertility (e.g., Rosenzweig and Wolpin 1980; Angrist and Evans 1998). Changes in legislation have also been used as instruments for fertility. Levine, Staiger, Kane and Zimmerman (1999) and Klerman (1999) find that the legalization of abortion in the United States led to a decrease in fertility. Angrist and Evans (1996) find that state-level legalization of abortion reduced fertility and increased the labor force participation of black women. Bailey (2006) uses state-level variations in contraceptive pill legislation as an instrument for fertility, and finds an effect of fertility on labor force participation.

In our analysis we use country level abortion legislation as an instrument for fertility. Henshaw, Singh and Haas (1999) estimate that worldwide around 26 percent of pregnancies end in abortion, making it a common method of avoiding childbirth. 
Although the precise timing of abortion laws may be considered random, this type of liberal legislation may reflect broader trends in society that are also correlated with female labor market participation. We control for these social factors by including both country fixed effects and country-specific time trends in our analysis.

Mammen and Paxson (2000), expanding on work by Goldin (1995), find the relationship between female participation rates and per capita income to be U-shaped. In poor, agricultural economies, female participation is high as family responsibilities and agricultural work can easily be combined. Female participation is lowest in urbanized, middle-income countries that are dominated by a manufacturing sector. Low levels of female education, the income effect of male earnings, and the separation of home and work environments contribute to lower participation rates. Female participation rates are again high in high-income countries with large service sectors and highly educated women. This reflects the role of urbanization in female labor force participation, which we control for in our analysis.

Our empirical results imply that the effect of fertility on female labor supply is strongest during the fertile years (20-39 years of age). We find a high degree of persistence in labor market participation, so that higher total fertility is associated with lower female labor force participation even at older ages. On average, our results imply that with each additional child, female labor force participation decreases by about 10-15 percentage points in the age group 25-39, and about 5-10 percentage points in the age group 40-49. These results imply a reduction of about four years of paid work over a woman's lifetime for each birth.

To illustrate the growth effects of the demographic transition with endogenous labor supply, we simulate long-run income dynamics using a simple production function model. We calibrate the model using data for South Korea, which saw a reduction in its total fertility rate from 5.6 children per woman in 1962 to 1.2 in 2002. The decline in fertility has three main effects. First, lower fertility implies lower population growth, and thus increases the capital-to-labor ratio in the standard Solow model. In our simulations, 
this effect leads to an increase in per capita income of about 36 percent over the period. Second, the fertility reduction increases the ratio of working-age population to total population by lowering the youth dependency ratio. Keeping age- and sex-specific participation rates steady at their 1960 levels, this age structure effect raises the relative size of the labor force, leading to a 47 percent increase in per capita income. Third, the fertility reduction increases female labor force participation. Using our point estimates from the empirical section, we find that the increase in female labor force participation generates a further gain in income per capita of 21 percent.

The combination of these effects ${ }^{2}$ implies an increase in income per capita by a factor of around 2.4. Although this is only a portion of the almost eleven-fold rise in income per capita that South Korea saw over the period, the reduction in fertility and increase in labor supply per capita may help explain this apparent growth "miracle” (Bloom, Canning et al. 2000). Although labor supply per capita is bounded above, and so cannot affect the rate of economic growth in the very long run, it can give a substantial boost to growth over a medium period of fifty years. If the transition from high fertility to low fertility is permanent, then there are long-run effects on age structure and persistent effects on female labor supply, and the gains in income per capita may be permanent.

A common finding in the empirical growth literature is that there is little relationship between the rate of population growth and the rate of growth of income per capita (see, e.g., Simon 1989). Our results do not invalidate this. We argue that a decline in population growth associated with a decrease in fertility can produce economic growth. However, if slow rates of population growth are due to ill health and high mortality, positive growth effects do not yield. Even though population growth has little correlation with economic growth, fertility and mortality rates considered separately appear to have large effects (Bloom and Freeman 1987; Kelley and Schmidt 1995).

\footnotetext{
${ }^{2}$ The effects are roughly multiplicative, even though the labor supply effects tend to reduce the capital/labor ratio somewhat.
} 
This paper is structured as follows: in section two, we present a model of labor supply and fertility. In section three, we present the data, and in section four, we discuss abortion legislation as an instrument for fertility. In section five we present the empirical results, and in section six, we discuss our simulation framework and show the simulation results of the medium-run effects of fertility decline on per capita income. We conclude with a summary and discussion.

\section{Model}

We propose a simple model of female fertility and labor supply choices. The utility function $U$ for a representative woman is defined over consumption $c$, leisure $d$, and fertility $n$. It is assumed to be given by:

$$
U(c, d, n)=\log \left(c+c_{0}\right)+\alpha \log (d)+\beta \log (n)-k \log \left(\frac{N}{n}\right)
$$

For simplicity we assume a logarithmic functional form. The weight on consumption is normalized to 1 . The relative weight of leisure in utility is $\alpha>0$, while the relative weight given to children is $\beta>0$. We might think of $c_{0}$ as being negative and representing subsistence consumption. Alternatively, $c_{0}$ might be taken to be positive and reflect transfers from a working husband to the woman. In addition to the utility of children, we assume there is a psychological cost $k$ of avoiding childbirth and achieving fertility lower than $N$, the potential reproductive capacity (or fecundity rate), usually taken to be around 15 on average. Obviously, actual fertility is usually regulated to be lower than this maximum. This regulation usually takes the form of delayed marriage, contraceptive use, abortion, or postpartum insusceptibility due to abstinence and breastfeeding after birth (Bongaarts 1984).

Total time available is normalized to one. This is divided between working time $l$, leisure time $d$, child care $b n$ and other non-market household work $\varepsilon$. That is,

$$
1=l+d+b n+\varepsilon
$$

The time allocated to child care is assumed to be linear in the number of children, with a time cost per child $b$. We assume $b>0$ and $0 \leq \varepsilon<1$. A woman's consumption 
possibilities are limited by the amount of income she earns: the prevailing wage $w$ times the amount of time she spends working $l$. All income earned is consumed, and the consumption constraint is defined as

$$
c=w l
$$

We assume $w(1-\varepsilon)+c_{0}>0$, so that consumption above the subsistence level is feasible. We treat constraints (1.2) and (1.3) as binding; if they are regarded as inequality constraints the fact that consumption and leisure time are always desirable will make them binding under maximization. Given these time allocation and consumption constraints we can write utility as a function of labor supply and the number of children:

$$
V(n, l)=\log \left(w l+c_{0}\right)+\alpha \log (1-l-b n-\varepsilon)+\beta \log (n)-k \log \left(\frac{N}{n}\right)
$$

where $0 \leq n \leq N$ and $0 \leq l \leq 1$.

The first order conditions for an interior maximum with respect to $l$ and $n$ are:

$$
\begin{gathered}
\frac{d V}{d l}=\frac{w}{w l+c_{0}}-\frac{\alpha}{1-l-b n-\varepsilon}=0 \\
\frac{d V}{d n}=\frac{\beta}{n}+\frac{k}{n}-\frac{\alpha b}{1-l-b n-\varepsilon}=0
\end{gathered}
$$

In Appendix A we show that the Hessian matrix is negative semi-definite, which implies that the first-order conditions above generate a local maximum. Given a fixed number of children $n$ the optimal labor supply is given by

$$
l=\frac{1}{1+\alpha}\left(1-\frac{\alpha c_{0}}{w}-b n-\varepsilon\right)
$$

while given a fixed labor supply $l$ the optimal number of children is

$$
n=\frac{\beta+k}{b(\alpha+\beta+k)}(1-l-\varepsilon) \text {. }
$$

We wish to estimate the structural equation (1.7) to find the effect of variations in fertility on female labor supply. The optimal labor supply is decreasing in fertility and the 
slope of the relationship depends on the time cost of children and the relative weights of consumption and leisure in utility. There is a possibility that the time required by other non-market household work $\varepsilon$ is random and not observed, which will create an error term in the estimation of equation (1.7). However, the non-market work time required also affects fertility in equation (1.8). Both fertility and labor supply are thus jointly determined and the parameters of equation (1.7) will not be identified in a simple regression. However, solving equations (1.7) and (1.8) for fertility we have

$$
n^{*}=\frac{(\beta+k)\left(c_{0}+w(1-\varepsilon)\right)}{b w(1+\alpha+\beta+k)},
$$

and

$$
\frac{d n^{*}}{d k}=\frac{\left(c_{0}+w(1-\varepsilon)\right)(1+\alpha)}{b w(1+\alpha+\beta+k)^{2}}>0 .
$$

This implies that optimal fertility is high when the cost of fertility control is high. The cost of fertility control is correlated with the fertility decision, but is not correlated with the error term in labor supply given by equation (1.7). The cost of fertility control affects labor supply only through its effect on the level of fertility. It follows that the cost of fertility control can be used as an instrument for fertility in estimating equation (1.7).

The wage rate affects both fertility and labor supply. The effect depends on the balance of income and substitution effects. If $c_{0}>0$, the substitution effect dominates, and, conditional on fertility, labor supply is rising with female wages. On the other hand, if $c_{0}<0$, the income effect dominates, and for a given fertility female labor supply is declining in the wage rate.

We estimate the causal negative effect of fertility on labor supply, holding everything else constant, as given by equation (1.7). Note, however, that fertility and labor supply can rise together if some of the parameters in our model change. For example, a decrease in $\varepsilon$, the time required for non-child related work in the home, can increase both fertility and female labor supply, which is consistent with the positive 
correlation between female labor supply and fertility in OECD countries found by Engelhardt and Prskawetz (2004).

\section{Data}

The data set we use in our empirical work is an unbalanced five-year panel covering the period from 1960 to 2000 for 97 countries. ${ }^{3}$ The dependent variable in our empirical analysis is female labor force participation. Labor market participation data are taken from the International Labor Organization (2007) and cover all age groups between 15-19 years old and 60-64 years old in five-year age increments. The International Labor Organization (ILO) data are based on national labor market surveys and censuses. The female participation rate is the number of economically active women divided by the total female population in the same age group. Although definitions vary slightly across countries, a woman is classified as "economically active" if she is either employed or actively looking for work (ILO Bureau of Statistics 2007).

Our explanatory variables are the fertility rate, the percentage of the population living in urban areas, physical capital per working-age person, female life expectancy and the average years of schooling of men and women. We use the stock of physical capital per working-age person, female life expectancy and the education level of women as a proxy for the wage rate. The education level of men serves as a proxy for male income and intra-family transfers, even though male education may also directly affect female wages if male and female human capital are substitutes.

Total fertility rates, female life expectancy and urbanization rates are from the World Development Indicators (World Bank 2006). The physical capital stock is from the Penn World Tables 6.2 (Heston, Summers et al. 2006), deflated by the working-age population rather than the number of workers as would be more usual, to avoid potential simultaneity biases in our estimation. Our human capital measures are the average years

\footnotetext{
${ }^{3}$ For a full list of countries, please see Appendix Table A2.
} 
of schooling in the female and male population aged 15 and older, respectively, as measured by Barro and Lee (2000).

Table 1 provides summary statistics for our main variables; a more detailed description of the data and data sources is provided in Appendix Table A1. The total fertility rate ranges from 1.18 (Spain and Italy in 1995) to 8.5 (Rwanda in 1980), with an average in the panel of 4.35. The average female labor force participation shows little variation across age groups, but great variation across countries for each age group. Figure 1 shows average female participation rates for women aged 15-64 in 2000. These range from values close to 90 percent in Tanzania and Mozambique to only 20 percent in Egypt, and show a pronounced U-shape. Figure 2 shows the change in participation over the period 1980 to 2000. Although a general increase in female labor force participation is visible in the data, and particularly pronounced in high-income countries, there is sizable variation in participation rates, ranging from an increase of more than 25 percent in Ecuador, Peru and Kuwait to a decrease of nearly 20 percent in Turkey.

[Table 1]

\section{Abortion Legislation as an Instrument for Fertility}

To construct an instrument for fertility we use data on national abortion legislation compiled by the United Nations Population Division (United Nations Population Division 2002). The data contain detailed information on the availability of abortion over time. ${ }^{4}$ We use the United Nations system to classify the laws in place. The United Nations system classifies seven legal reasons for an abortion: to save the life of the woman; to preserve her physical health; to preserve her mental health; consequent on rape or incest; fetal impairment; economic or social reasons; and available on request. Our data contain indicator variables for each of these seven categories. A "1" indicates that abortion is available for the given reason, and "0" means that it is not. When an abortion is available on request, we assume availability for any of the other reasons if this is not explicitly stated.

\footnotetext{
${ }^{4}$ We are grateful to Mansour Farahani for compiling the data.
} 
Although these categories are broad, they are not comprehensive descriptions of abortion law. There are frequently cutoffs for lawful abortions depending on the length of the pregnancy. The mechanisms for adjudicating if a pregnancy meets a particular criterion differs across countries, relying in some cases on a single doctor, while in others two are more doctors are required to agree. In some countries a husband's consent is required. The United Nation coding scheme ignores these additional factors and declares an abortion for a particular reason lawful if it is allowed at any time during the pregnancy. In federal systems, abortion laws sometimes differ across regions. In this case the law that covers the majority of the population, if one exists, is used to classify at the national level.

We use the values of these variables as coded by the United Nations to provide a value for the most recent year at which data are available. For earlier years we recode the variable to reflect a country's legal situation at a given time as set out in the United Nations documentation of abortion legislation history. This recoding is complicated by the need to consider not only statutes that relate to abortion, but also the evolution of case law in the interpretation of those statutes.

In many countries there is a divergence between law and practice, with abortions being widely available despite being technically illegal, or vice versa. We take the objective stance and code according to the law. For example, in the United Kingdom (excluding Northern Ireland) the Abortion Act of 1967 allows abortion to protect the life, physical and mental health of the mother, and in cases where there is a risk the child will be handicapped. The law also covers cases where a birth might affect the health of existing children and allows the woman's actual and potential environment to be taken into account. Legally, abortion is not explicitly available in the case of rape or simply on request. Although this is the legally restricted set of criteria, in practice the physical and mental health criteria appear to be interpreted liberally. They include the effects of childbirth on socio-economic circumstances and hence health outcomes so that de facto an abortion is available if a woman requests one. In the case of rape a claim that abortion 
was needed to preserve the mental and physical health of the mother would be very likely to succeed (as in the case of Rex v. Bourne, 1938). A second example is Chile. The law of 1874 prohibited abortions carried out with malice; it was understood that abortions to save the life of the mother were permitted. This was explicitly recognized in the law of 1967. The law was changed in 1989 to outlaw abortions in all circumstances (though some commentators suggest that a defense of necessity to save the life of the mother would succeed). Despite these strict laws, abortion has been relatively common in Chile throughout the period. We code Chile as allowing abortion to save the life of the mother from 1960 to 1988 and as not allowing abortion under any circumstances thereafter.

Table 1 summarizes the abortion data. The "life threatening" indicator has an average of 0.95, which implies that almost all countries across the sample period allow abortion under this circumstance. There is more variation across countries and time for the availability of abortion on the remaining categories. We construct an index summarizing the availability of abortion. A country gets a score of zero if abortion is not legal for any reason. One is added to the score for each circumstance in which abortion is available, with a maximum score of 7 .

Although we found these abortion indicators to have significant explanatory power as a group, it is difficult to find independent effects for the different indicators. Table 2 shows the correlation matrix for the abortion variables. Apart from abortion when the pregnancy threatens the life of the mother, which is almost universally allowed, the other indicators are highly collinear. We find that each abortion variable has significant explanatory power for fertility when used singularly, but additional abortion variables add little to the fit of the first-stage regression. Accordingly, using more than one variable may lead to a weak instrument problem, increasing the finite sample estimation bias. Using multiple instruments would have the potential advantage of allowing an overidentifying restrictions test of instrument validity; when we use multiple instruments we indeed pass this test. However, this test relies on at least one instrument being valid and lacks appeal in our context when the intuitive justification for each instrument is the same, and it is likely that either all, or none, of our instruments are valid. These issues are 
discussed in more detail in Murray (2006), and lead us to use only one instrument in our analysis. Rather than using one of the raw abortion measures we use an abortion index giving equal weight to each measure in an aggregate; this index has a slightly higher predictive power for fertility than any single abortion measure.

As an alternative to using a simple additive index, one might consider using the principal component of the seven abortion variables in the empirical analysis. As can be seen in Table 2, the first principal component is virtually identical to the index we use in our empirical specification. The correlation between the abortion index and the first principal component is 0.997 . The weight assigned to each of the abortion indicators in the construction of the first principal component, shown on the final row of Table 2, is almost identical for each measure (except for the "life threatening" category) making it very similar to an additive index. For ease of interpretation, we use the abortion index rather than the first principal component.

Our abortion index is correlated with fertility, but a key issue is that for abortion legislation to be a valid instrument it must be uncorrelated with the error term in the female labor market participation regression. It seems likely that the only way that abortion laws affect labor market participation is through their effect on fertility. We measure the effect through the total fertility rate. The total fertility rate is the number of births a woman would have if she experienced the current age-specific fertility in the population; this is a period rather than cohort measure. Thus it captures permanent shifts in fertility as well as temporary shifts due to changes in the timing of births.

The instrument validity condition will hold if abortion legislation occurs randomly, but this is highly unlikely. There are two ways instrument validity may break down if abortion legislation is not random. The first is that abortion legislation is endogenously responding to fertility desires, or to female labor force participation, so that the direction of causality is the opposite to what we require of an instrument. The second is that there are some unobserved variables, perhaps social or cultural norms, which influence both abortion legislation and female labor force participation. We control for the unobserved national social and cultural norms in our analysis using country fixed 
effects, and country-specific time trends. This allows the average level and time trend of the abortion index in a country to be endogenous. We identify the effect from abortion legislation that deviates from the average level and time trend of the abortion legislation index in that country. Although the level and time trend in abortion legislation may be endogenous, we take the exact timing of abortion legislation, which generates deviations from these long-term trends, to be random.

To examine the issue of reverse causality from fertility or female labor market participation to abortion legislation we carry out Granger causality tests. The tests seek to determine if lagged female labor force participation of a specific cohort and fertility are predictive of abortion legislation. Table 3 reports the results of a regression of our abortion legislation index on two lags of its own value, the female participation rate of 25-29 year olds (the age group whose participation we find is most sensitive to fertility) and the total fertility rate. The first column includes worldwide time dummies, the second column adds country fixed effects, while the third adds country-specific linear time trends. The results in the first column suggest that a low fertility rate and high female labor force participation rate are predictive of a higher value of the abortion legislation index. However, this predictive power disappears in columns 2 and 3 of Table 4 when we add country fixed effects (column 2) and country-specific time trends (column 3). These results are consistent with the view that there are country-specific cultural factors that drive fertility, female labor force participation, and abortion legislation. However, once we control for these generic differences in levels and trends using country fixed effects and time dummies, movements in the abortion law appear random.

\section{[Table 3]}

An alternative potential instrument in this context could be the measure of family planning program effort compiled by Ross and Stover (2001). The family planning effort score provides an aggregate of 30 scores on a range of variables that measure a government's commitment to family planning. We find that there is a positive correlation between these effort scores and our abortion law index. We do not use the effort scores as 
an instrument because of evidence that some of the scores measured may be highly responsive to the demand for family planning (Kelly and Cutright 1983).

A final point about our instrument is that we treat the estimates as identifying a single effect of fertility on female labor market participation. If there is heterogeneity in the response across women, and abortion legislation only affects the fertility of a subgroup of the population, it is the average labor market response to fertility within this

subgroup (the local average treatment effect) that we measure, not the population average response.

\section{Empirical Specification and Results}

Equation 1.7 suggests that female labor force participation depends on the fertility rate, the wage rate, and intra-family transfers. We include the fertility rate in our empirical specification and proxy the wage rate of women by the ratio of capital per working-age person, female life expectancy, and the female education level. The level of intra-family transfers is captured using the male education level. In addition to these variables, we add the percentage of the population living in urban areas. In agricultural societies, the workplace is located around the family home, making it easier to simultaneously care for children and work. In urban areas, by contrast, the workplace is usually distinct from the home, making it more difficult to do both concurrently. Moreover, urbanization can also have a negative effect on female labor supply during the transition from agriculture to manufacturing. If working outside the home in manual labor carries a social stigma for women, this may reduce their labor market opportunities (Goldin 1995).

In our empirical work we estimate the following equation,

$$
\begin{aligned}
P_{i j t}= & \alpha_{i}+\beta_{i} \text { Fert }_{j t}+\gamma_{i} \operatorname{Cap}_{j t}+\varphi_{i} \text { Life }_{j t}+\lambda_{i} \text { Urban }_{j t} \\
& +\phi_{i}^{f} \operatorname{Eduf}_{j t}+\phi_{i}^{m} \text { Edum }_{j t}+\delta_{i t}+\delta_{i j}+\tau_{i j} t+\varepsilon_{i j t}
\end{aligned}
$$


where $P_{i j t}$ is the participation rate of females of age group $i$ in country $j$ at period $t$. Fert is the total fertility rate, Cap is the capital stock per working-age person, Life is female life expectancy, Urban is the percentage of the population living in urban areas, Edum is the average years of schooling of men while Eduf is the average years of schooling of women, $\delta_{i j}$ and $\delta_{i t}$ are country and year fixed effects, respectively, while $\tau_{i j}$ denotes country-specific time trends. Note that each of these fixed effects, time dummies, and time trends can vary by age group, $i$. The country fixed effects, time dummies and country-specific time trends allow for different labor market institutions and cultural norms across countries and over time.

The inclusion of fixed effects and country-specific time trends makes the model robust to unobserved heterogeneity, but comes at the cost of reducing the signal-to-noise ratio. We therefore start our empirical analysis by estimating the model with fixed effect but without country-specific time trends. The regression for the participation of each age group is run separately. The results are reported for ten groups aged 15-64, although the results for the first group, the age group 15-19, should be treated with caution because labor market participation in this group is reduced by school attendance. The results for this specification, without instrumentation, are summarized in Table 4 below.

Table 4 shows that the marginal effect of fertility on female labor force participation is negative and statistically significant for all age groups between 20 and 44 . Capital per working-age person, female life expectancy, and female education all appear to have positive and relatively large effects on female labor participation (at least for ages above 20). Male education reduces female labor market participation, which is consistent with male earnings producing an income effect that lowers female work incentives. The estimated coefficient on urbanization is negative; a 10 percentage point increase in urbanization leads to a decrease in female labor force participation of between 2 and 5 percentage points. This effect implies high participation in rural economies, even when female wages may be low.

\section{[Table 4]}


In Table 5, we use the abortion index as an instrument in a two-stage least squares estimation as an alternative specification. The estimated fertility effects are very large: according to the instrumental variable (IV) estimates, a unit decrease in the total fertility rate leads to an increase of 5 to 17 percentage points in female labor force participation.

The point estimates from the IV estimation appear large in absolute magnitude relative to the OLS estimates presented in Table 4. If higher female labor supply depresses fertility, the OLS estimate should be larger, and not smaller than the IV estimate. One possible explanation for this finding is that measurement error may attenuate the OLS estimates but not the instrumental variable estimate. Another possible explanation is that fertility and female labor supply are positively correlated due to some unobserved variables (for example, the non-child-care time required for household tasks), so that instrumentation reduces this omitted variable bias.

The bottom half of Table 5 reports the first-stage estimation of fertility. The estimated effect of abortion laws on fertility is relatively small. The maximum increase in the abortion index (from 0 to 7 ) leads to a predicted reduction in fertility of about 0.5 children. This effect appears reasonable, but is relatively small compared to the average change in fertility rates observed in the sample period. The first stage F-statistic larger than 16 suggests that abortion laws are highly predictive in the first-stage regression.

\section{[Table 5]}

In the OLS estimates in Table 4, female education is associated with higher female labor market participation, while male education is associated with lower female participation. In Table 5, when fertility is instrumented, these education effects on female participation are not statistically significant. Note, however, that education has strong effects on fertility in the first-stage regression reported in Table 5. Fertility falls as female education levels rise, but rises with male education levels. Because the effect of female education is larger, an equal rise in education for both sexes implies lower fertility. It 
follows that, conditional on fertility, education may not be very significant in the participation equation, but it still has a large impact on female labor market participation through its effect on fertility. This is similar to the argument by Smith and Ward (1985) that the effect of higher female wages on female labor supply works partly through fertility reductions.

Although we control for country fixed effects and time dummies in the empirical specifications presented in the previous section, one may still worry about countryspecific trends that are not picked up by time fixed effects. As individual societies become westernized, more or less religious, or more open to trade, attitudes towards the female role in society may change, affecting abortion legislation, fertility, and female labor force participation. To control for such trends, we repeat the previous analysis allowing for a country-specific time trend. The results, which are summarized in Table 6, confirm our previous findings. The inclusion of a country-specific time trend slightly lowers the point estimates on capital, urbanization and fertility, but does not change our basic result: the average fertility response across the main age groups ranges from 6 to 12 percentage points.

\section{[Table 6]}

The effects of fertility on the labor participation of women appear to peak among 35-39 year olds, and are significant even for 50 year olds. We would expect fertility to affect mainly younger women. However, exit from the labor market due to fertility may have long-run effects if participation behavior is persistent. One reason for such persistence might be returns to experience, which lower the wages of women who temporarily exit the labor market relative to women who stay employed. To investigate this, we include lagged cohort participation in the specifications shown in Table 7. Because our lagged variable is the participation of a different age group - the age group five years younger in the previous time period - rather than lagged participation of the same age group, the problem of bias in a dynamic panel with short time dimension (Nickell 1981) does not apply. 
The results for the model with lagged participation included as an explanatory variable are reported in Table 7. First-stage results for this specification are displayed in Table 8. Note that the first stage for the 15-19 year olds (which does not include a lagged participation term) is the same as the first stage for fertility when we do not include a lag in the specification. This corresponds to the first stage of the static model reported in Table 6. Female education is again highly significant in the first-stage regressions, and education works indirectly through fertility rather than directly on labor market participation. The abortion index is also highly significant in the first-stage regression.

Even when controlling for country fixed effects, time dummies, a country-specific time trend, and a lagged cohort participation rate (Table 7), the highly significant negative effect of fertility on female labor force participation persists. The marginal effect of fertility is statistically significant for the age groups 20-24, 30-34 and 35-39, but highly relevant for all age groups given the persistence of female labor force participation. The significant coefficient on the lagged participation implies that the fertility effect on participation at young ages may impact female labor force participation throughout working life.

Although the dynamic framework reported in Tables 7 and 8 seems plausible, we regard the results from the static model reported in Table 6 as our preferred estimates. In the dynamic estimates, we need to assume the lagged cohort female labor force participation to be exogenous. If the disturbances in the model are auto-correlated, this assumption will not be valid. In principle, we can overcome this by instrumenting the lagged participation rate. However, lagged abortion has little predictive power for lagged participation, giving rise to the weak instrument problem. In a dynamic model with fixed effects, country-specific time trends, and lagged participation, proper identification of a 2SLS model becomes difficult.

Overall, our static and dynamic models give very similar estimates of the long-run effect of fertility on female labor market participation. Our estimates imply a reduction in 
paid work of 8 percent of a woman's potential working life, or 4 years of paid employment, for each child born.

\section{Simulations}

To illustrate the magnitude of the growth effects associated with the demographic transition, we provide simulation results. The Republic of Korea (South Korea) poses a prime example for a developing country moving through the demographic transition, and we calibrate our model to this economy. Total fertility rates in South Korea dropped from 5.6 children per woman in the early 1960s to 1.2 children in the period 2000-2005. According to the United Nations, fertility rates in the South Korea are expected to reach their low at 0.85 children in 2015 before gradually recovering to levels around 1.35 in the long run ${ }^{5}$ (World Population Prospects, 2004). As shown in Figure 4, the drop in fertility over the last 40 years has been accompanied by a rapid increase in female labor force participation rates: average participation in the age group 25-39 has risen from 26.6 percent in 1960 to 54.5 percent in 2000 (ILO Bureau of Statistics 2007).

\section{[Figure 4]}

The representative economy we simulate is based on a standard Cobb-Douglas production function with constant returns to scale. Total output $Y$ in each period $t$ is given by

$$
Y_{t}=A K_{t}^{\alpha} L_{t}^{1-\alpha}
$$

where $A$ is a productivity measure, $\mathrm{K}$ is the stock of physical capital, and $\mathrm{L}$ denotes the labor force. Technological progress and education are assumed to be constant and are included in the parameter $A$. We are interested in how changes in the fertility rate affect the labor force, the physical capital stock, and income per capita. The physical capital stock $K_{t}$ in each period $t$ is determined by

\footnotetext{
${ }^{5}$ The numbers cited reflect the United Nations' most conservative projections (low-fertility scenario). We use the low fertility scenario as it assumes a continuous decline in fertility for the next 15 years which is consistent with the trends in fertility observed over the past 20 years. Results using the other scenarios are very similar.
} 


$$
K_{t}=s Y_{t-1}+(1-\delta) K_{t-1},
$$

where $s$ is the aggregate savings rate and $\delta$ is the depreciation rate.

We initialize our simulations with the age structure in South Korea in 1960. The evolution of population numbers and age structure after 1960 in the simulation differ from the actual figures recorded in South Korea because we keep age-specific mortality rates fixed at their 1960 levels. ${ }^{6}$ Our simulation therefore only captures the effect of fertility decline on population, and not the impact of improved longevity. Modeling each male and female birth cohort separately, the population $P_{i t}^{s}$ of sex $s$, age $i$, and time $t$ is given by

$$
P_{i t}^{s}=P_{i-1, t-1}^{s}\left(1-\sigma_{i-1}^{s}\right) \text { for } i \geq 1, \quad P_{0 t}^{s}=\lambda_{s} \sum_{i=16}^{45} f_{i t} P_{i t}^{f}
$$

where $f_{t}$ is the age-specific fertility rate ${ }^{7}$ at time $t$, and $\lambda_{s}$ is the fraction of sex $s$ in births. To determine the size of the population we take the age- and sex-specific mortality rates $\sigma_{i}^{s}$ to be fixed at the 1960 levels. ${ }^{8}$ The sex ratio at birth is set at 51 percent male and 49 percent female, which corresponds to the makeup of the current adult population in South Korea. ${ }^{9}$

The labor force $L_{\mathrm{t}}$ used in production in each period $t$ is given by

$$
L_{t}=\sum_{i=0}^{100} \sum_{s=m, f} P_{i t}^{s} \rho_{i t}^{s},
$$

where $\rho_{i t}^{s}$ captures the age- and gender-specific labor participation rates at time $t$.

We assume capital and labor shares in income to be one third and two thirds respectively (so that $\alpha=1 / 3$ ). Our other baseline assumptions are a savings rate $s$ of 24

\footnotetext{
${ }^{6}$ We also perform alternative specifications with actual and predicted survival tables for the period 1960 to 2050. The results look very similar to the ones presented in this section.

${ }^{7}$ We assume that fertility is distributed uniformly over the fertile years as the exact age of birth is unknown in the aggregate data.

${ }^{8}$ Note that $\left(1-\sigma_{i}\right)$ is the survival probability between age $i$ and age $i+1$.

${ }^{9}$ In recent years, the percentage of female newborns has fallen to $47 \%$; we take the average of the last 30 years as our baseline assumption.
} 
percent and an annual capital stock depreciation rate of 8 percent. This gives a steadystate capital output ratio of three. Rather than estimating the capital stock for South Korea in 1960, we assume that the economy starts in steady state with a steady level of GDP per capita. This is the steady state that would have emerged if fertility rates, participation rates, and mortality schedules had remained at the 1960 levels. Because we consider only relative output levels, we set the level of total factor productivity $A$ to one without loss of generality.

The only exogenous variable that we change during the simulation is the fertility rate, for which we use the actual and forecast rates as published by the United Nations (2004). Although we assume that male participation rates remain constant at 1960 levels, we allow for female labor force participation to respond to the lower fertility in line with the estimates reported in Table 6.

We report our simulation results in Figure 5. The baseline is the steady-state income per capita level at constant 1960 fertility rates. We then consider the effect of the actual and predicted future decline in fertility rates relative to this baseline. We first estimate the Solow effect of lower population growth on the capital-labor ratio. Assuming that the ratio of workers to population is constant as in the standard Solow model, lower fertility rates imply lower population growth, a higher capital-labor ratio and higher output per capita. According to our model, income per capita rises by 36 percent if we take only this Solow effect into account.

\section{[Figure 5]}

However, falling fertility also translates to changes in the population age structure. Keeping age- and sex-specific participation rates constant at the 1960 levels, the "Solow plus age structure" effect in Figure 5 combines the Solow capital-labor effect with the high labor supply per capita due to a falling youth dependency ratio. Assuming that male and female (age-specific) participation rates do not change, the shift in age structure implies that the percentage of population working increases from 31 to 46 
percent in the long run. This leads to an additional 47 percent in steady-state output per capita over and above the Solow effect. ${ }^{10}$ It should be noted that the transition is not monotonic. The rapid decline in fertility generates a "baby boom cohort," whose members produce high output during their working age, but also a high old-age dependency rate once they retire. This cohort effect is very mild in our simulation. Even when we include the effect of longer life spans on age structure, the decrease in the youth dependency generated by the fertility decline dominates the increase in old-age dependency, such that the overall dependency rate declines. This effect is even stronger when old-age participation rates are high as is the case in South Korea.

The effects on income per capita are even bigger once we allow for female labor market participation to adjust to lower fertility. Using our point estimates from Table 6 to simulate the female labor supply responses, we find that the female labor supply response leads to an additional increase of steady-state income per capita of 21 percent relative to the scenario with the Solow and age structure effect. Combining all effects implies an increase in steady-state per capita income of 141 percent relative to the base line. ${ }^{11}$ The results suggest that reductions in fertility increased the growth rate of per capita income in South Korea by 1.9 percent per year between 1960 and 1990. Between 1990 and 2020 the effect is smaller, increasing the growth rate by 1.2 percent per year. Our simulation suggests that economic growth from this source will end around 2020, but that the high level of income attained due to low fertility will persist.

Our simulation examines only the effects of fertility decline. In fact, since 1960 there have been large reductions in mortality rates in South Korea, particularly at older ages, while old-age labor market participation rates have declined. Including these effects in the simulation reduces the gain in income per capita somewhat and produces a more pronounced downturn in income per capita after 2020 due to population aging and earlier retirement, though the long run steady-state income level stays well above its 1960 level.

\footnotetext{
${ }^{10}$ The effects do not add up linearly because the capital-labor ratio "Solow" effect is somewhat reduced by higher labor force participation.

${ }^{11}$ The individual effects multiply each other; 36 percent Solow effect is multiplied by 47 percent from age structure and 21 percent from the female labor supply response: $(1.36 \times 1.47 \times 1.21=2.41)$.
} 


\section{Discussion and Conclusions}

The concept of the "demographic dividend" (Bloom, Canning et al. 2001; Bloom, Canning et al. 2003) elucidates the economic benefits that a country can gain if it experiences a decline in fertility. The decline in fertility reduces population growth, and increases the capital-labor ratio. At the same time, the shift in fertility increases the ratio of working-age to total population; compounding this is the positive behavioral response of female labor force participation, which further increases labor supply per capita. Using a simulation model, our parameter estimates suggest that the effects of fertility reduction on income levels can be large - more than doubling the steady-state level of output per capita.

In this paper, we have only considered the effect of fertility on female labor supply. The model presented here does not account for the possible effect on education of a decline in fertility. Increased female labor supply may raise the economic returns to women's schooling, providing positive incentives for women to invest in education. The effect of fertility on saving is another important aspect not taken into account. To the extent that children provide old-age support to their parents, a decline in fertility may increase financial savings for old age and retirement. The decline in fertility may also have beneficial effects on long-run economic growth by allowing greater investment in children's health and education. These mechanisms suggest that the overall effect of a fertility decline on economic growth may be even larger than we report. 


\section{References}

Angrist, J. and W. Evans (1998). "Children and Their Parents' Labor Supply: Evidence from Exogenous Variation in Family Size." American Economic Review 88(3): 450-477.

Angrist, J. D. and W. N. Evans (1996). "Schooling and Labor Market Consequences of the 1970 State Abortion Reforms." NBER Working Paper W5406.

Bailey, M. J. (2006). "More power to the pill: The impact of contraceptive freedom on women's lifecycle labor supply." Quarterly Journal of Economics 121 (1): 289-320.

Barro, R. J. and J.-W. Lee (2000). "International Data on Educational Attainment: Updates and Implications." CID Working Paper 42.

Bloom, D. E., D. Canning, et al. (2000). "Population Dynamics and Economic Growth in Asia." Journal of Population Economics 26(supp.): 257-90.

Bloom, D. E., D. Canning, et al. (2007). "Demographic Change, Social Security Systems, and Savings." Journal of Monetary Economics 54(1): 92-114.

Bloom, D. E., D. Canning, et al. (2001). "Economic Growth and the Demographic Transition." NBER Working Paper(8685).

Bloom, D. E., D. Canning, et al. (2003). "The Demographic Dividend: A New Perspective on the Economic Consequences of Population Change." RAND Monograph Report.

Bloom, D. E. and R. B. Freeman (1987). "Population Growth, Labor Supply, and Employment in Developing Countries." Population growth and economic development: Issues and evidence.

Bloom, D. E. and J. G. Williamson (1998). "Demographic transitions and economic miracles in emerging Asia." World Bank Economic Review 12(3): 419-455.

Bongaarts, J. (1984). "Implications for future fertility trends for contraceptive practice." Population and Development Review 10(2): 341-352.

Brander, J. A. and S. Dowrick (1994). "The Role of Fertility and Population in Economic Growth." Journal of Population Economics 7(1): 1-25.

Browning, M. (1992). "Children and Household Economic Behavior." Journal of Economic Literature 30(3): 1434-1475.

Engelhardt, H. and A. Prskawetz (2004). "On the changing correlation between fertility and female employment over space and time." European Journal of Population 20: 35-62. 
Goldin, C. (1995). The U-Shaped Female Labor Force Function in Economic Development and Economic History. Investment in Women's Human Capital and Economic Development. T. P. Schultz. Chicago, IL, University of Chicago Press: 61-90.

Henshaw, S. K., S. Singh, et al. (1999). "The Incidence of Abortion Worldwide." International Family Planning Perspectives 25(Supplement): S30-S38.

Heston, A., R. Summers, et al. (2006). "Penn World Table Version 6.2." Center for International Comparisons of Production, Income and Prices at the University of Pennsylvania.

ILO (1997). Economically Active Population, 1950-2010. Geneva.

ILO Bureau of Statistics (2007). ILO Database on Labour Statistics, International Labour Organization.

Kelley, A. C. and R. M. Schmidt (1995). "Aggregate Population and Economic Growth Correlations: The Role of the Components of Demographic Change." Demography 32(4): 543-555.

Kelly, W. R. and P. Cutright (1983). "Determinants of national family planning effort." Population Research and Policy Review 2(2): 111-130.

Klerman, J. A. (1999). "U.S. Abortion Policy and Fertility " The American Economic Review 89(2): 261-264.

Levine, P. B., D. Staiger, et al. (1999). "Roe v Wade and American fertility." American Journal of Public Health 89(2): 199-203.

Mammen, K. and C. Paxson (2000). "Women's Work and Economic Development." The Journal of Economic Perspectives 14(4): 141-164.

Murray, M. P. (2006). Econometrics: A Modern Introduction. Boston, Addison-Wesley. Nickell, S. (1981). "Biases in dynamic models with fixed effects." Econometrica 49(6): 1417-1426.

Rosenzweig, M. R. and K. I. Wolpin (1980). "Testing the Quantity-Quality Fertility Model: The Use of Twins as a Natural Experiment." Econometrica 48(1): 227-240.

Ross, J. and J. Stover (2001). "The family planning program effort index: 1999 cycle." International Family Planning Perspectives 27(3): 119-129.

Simon, J. L. (1989). "On Aggregate Empirical Studies Relating Population Variables to Economic Development." Population and Development Review 15(2): 323-332. 
Smith, J. P. and M. P. Ward (1985). "Time-Series Growth in the Female Labor Force." Journal of Labor Economics 3(1): 59-90.

United Nations (2004). World Population Prospects CD-ROM.

United Nations Population Division. (2002). "Abortion Policies: A Global Review." 2007, from http://www.un.org/esa/population/publications/abortion/index.htm.

World Bank (2006). "World Bank Development Indicators CD-ROM." 
Table 1: Summary Statistics

\begin{tabular}{|c|c|c|c|c|}
\hline Variable Name & Mean & Std. Dev. & Min & $\overline{\text { Max }}$ \\
\hline Abortion: Pregnancy Life Threatening & 0.95 & 0.21 & 0 & 1 \\
\hline Abortion: Pregnancy Threatening Physical Healtt & 0.56 & 0.50 & 0 & 1 \\
\hline Abortion: Pregnancy Treatening Mental Health & 0.52 & 0.50 & 0 & 1 \\
\hline Abortion: Rape & 0.37 & 0.48 & 0 & 1 \\
\hline Abortion: Fetal Impairment & 0.32 & 0.47 & 0 & 1 \\
\hline Abortion: Economic Reasons & 0.22 & 0.42 & 0 & 1 \\
\hline Abortion: Request & 0.17 & 0.37 & 0 & 1 \\
\hline Abortion Index & 3.11 & 2.29 & 0 & 7 \\
\hline Total Fertility Rate & 4.35 & 2.04 & 1.18 & 8.50 \\
\hline Average years of schooling, male, age >15 & 5.4 & 2.8 & 0.3 & 12.2 \\
\hline Average years of schooling, female, age $>15$ & 4.5 & 3.0 & 0.0 & 12.0 \\
\hline Capital per Working Age Person & 23.2 & 27.4 & 0.3 & 138.2 \\
\hline Female Life Expectancy at birth & 64.1 & 12.6 & 33.4 & 84.6 \\
\hline Urban population (\% of total) & 48.1 & 24.7 & 3.2 & 100 \\
\hline Real GDP per capita (Real 2004 \$, PPP) & 7,340 & 7,531 & 171 & 64,640 \\
\hline Female Participation Age 15-19 & 39.0 & 19.0 & 3.6 & 89.0 \\
\hline Female Participation Age 20-24 & 55.8 & 18.4 & 12.2 & 100.0 \\
\hline Female Participation Age 24-29 & 55.7 & 19.8 & 10.9 & 100.0 \\
\hline Female Participation Age 30-34 & 55.7 & 21.4 & 12.5 & 100.0 \\
\hline Female Participation Age 35-39 & 56.5 & 22.4 & 11.9 & 100.0 \\
\hline Female Participation Age 40-44 & 56.5 & 22.7 & 11.7 & 100.0 \\
\hline Female Participation Age 45-49 & 54.7 & 23.0 & 8.7 & 100.0 \\
\hline Female Participation Age 50-54 & 50.2 & 22.8 & 5.4 & 98.0 \\
\hline Female Participation Age 55-59 & 43.3 & 22.7 & 3.1 & 94.2 \\
\hline Female Participation Age 60-64 & 33.1 & 21.8 & 1.2 & 88.9 \\
\hline
\end{tabular}


Table 2: Correlation between Abortion Laws

\begin{tabular}{|c|c|c|c|c|c|c|c|c|}
\hline & $\begin{array}{c}\text { Life } \\
\text { Threatening }\end{array}$ & $\begin{array}{c}\text { Mother's } \\
\text { Physical } \\
\text { Health }\end{array}$ & $\begin{array}{l}\text { Mother's } \\
\text { Mental } \\
\text { Health }\end{array}$ & Rape & $\begin{array}{c}\text { Fetal } \\
\text { Impairment }\end{array}$ & $\begin{array}{l}\text { Economic } \\
\text { at Reasons }\end{array}$ & Request & $\begin{array}{l}\text { Abortion } \\
\text { Index }\end{array}$ \\
\hline Life Threatening & 1.000 & & & & & & & \\
\hline Physical Health & 0.238 & 1.000 & & & & & & \\
\hline Mental Health & 0.221 & 0.932 & 1.000 & & & & & \\
\hline Rape & 0.165 & 0.616 & 0.587 & 1.000 & & & & \\
\hline Fetal Impairment & 0.157 & 0.633 & 0.629 & 0.836 & 1.000 & & & \\
\hline Economic Reasons & 0.135 & 0.542 & 0.578 & 0.745 & 0.813 & 1.000 & & \\
\hline Request & 0.120 & 0.505 & 0.542 & 0.715 & 0.754 & 0.875 & 1.000 & \\
\hline Abortion Index & 0.273 & 0.828 & 0.834 & 0.870 & 0.900 & 0.873 & 0.839 & 1.000 \\
\hline First Principal Component & 0.253 & 0.815 & 0.822 & 0.874 & 0.906 & 0.883 & 0.850 & 1.000 \\
\hline First Princ. Comp. Weight & 0.136 & 0.399 & 0.395 & 0.402 & 0.430 & 0.410 & 0.389 & \\
\hline
\end{tabular}


Table 3: Granger Causality Tests on the Abortion Index

\begin{tabular}{lccc}
\hline \hline & \multicolumn{2}{c}{ Dependent Variable: Abortion Index } \\
\hline Abortion Index ( $\mathrm{t}-5)$ & $0.856^{* * *}$ & $0.483^{* * *}$ & $0.132^{* * *}$ \\
& $(0.032)$ & $(0.080)$ & $(0.042)$ \\
Abortion Index ( $\mathrm{t}-10)$ & $0.035^{*}$ & $-0.069^{* *}$ & $-0.231^{* * *}$ \\
& $(0.019)$ & $(0.032)$ & $(0.043)$ \\
Fertility (t - 5) & $-0.274^{* *}$ & -0.162 & -0.254 \\
& $(0.132)$ & $(0.149)$ & $(0.181)$ \\
Fertility (t - 10) & 0.172 & 0.237 & 0.151 \\
& $(0.124)$ & $(0.158)$ & $(0.189)$ \\
Participation Rate 25-29 (t - 5) & $0.019^{*}$ & 0.010 & 0.020 \\
& $(0.010)$ & $(0.011)$ & $(0.014)$ \\
Participation Rate 25-29 (t - 10) & $-0.016^{*}$ & 0.002 & -0.000 \\
& $(0.009)$ & $(0.010)$ & $(0.017)$ \\
Time Dummies & Yes & Yes & Yes \\
Country Fixed Effects & No & Yes & Yes \\
Country Time Trends & No & No & Yes \\
Observations & 576 & 576 & 576 \\
R-squared & 0.84 & 0.90 & 0.95 \\
F-stat p-value (Fertility) & $0.00^{* * *}$ & 0.31 & 0.37 \\
F-test p-value (Participation Rate) & 0.18 & 0.22 & 0.28 \\
F-test p-value (Fertility and Participation Rate) & $0.01^{* * *}$ & 0.41 & 0.19 \\
\hline Notes: & & & \\
Robust standard errors in parentheses & & & \\
* significant at 10\%; ** significant at 5\%; ** significant at $1 \%$ & & & \\
\hline \hline & & & \\
\end{tabular}


Table 4: Female Labor Force Participation, Fixed Effects Estimation

\begin{tabular}{|c|c|c|c|c|c|c|c|c|c|c|}
\hline & \multicolumn{10}{|c|}{ Dependent Variable: Female Labor Force Participation, by Age Group } \\
\hline & $15-19$ & $20-24$ & $25-29$ & $30-34$ & $35-39$ & $40-44$ & $45-49$ & $50-54$ & 55-59 & $60-64$ \\
\hline Total Fertility Rate & $\begin{array}{c}0.703 \\
(0.554)\end{array}$ & $\begin{array}{c}-2.359 * * * \\
(0.613)\end{array}$ & $\begin{array}{c}-3.094 * * * \\
(0.643)\end{array}$ & $\begin{array}{c}-2.386 * * * \\
(0.684)\end{array}$ & $\begin{array}{c}-1.570 * * \\
(0.707)\end{array}$ & $\begin{array}{l}-1.291 * \\
(0.682)\end{array}$ & $\begin{array}{c}-0.203 \\
(0.642)\end{array}$ & $\begin{array}{c}0.202 \\
(0.584)\end{array}$ & $\begin{array}{c}0.859 \\
(0.529)\end{array}$ & $\begin{array}{l}-0.110 \\
(0.377)\end{array}$ \\
\hline Female life expectancy & $\begin{array}{c}0.344 * * * \\
(0.075)\end{array}$ & $\begin{array}{c}0.312^{* * *} \\
(0.089)\end{array}$ & $\begin{array}{c}0.117 \\
(0.084)\end{array}$ & $\begin{array}{c}0.136 \\
(0.091)\end{array}$ & $\begin{array}{l}0.275^{* *} \\
(0.113)\end{array}$ & $\begin{array}{l}0.169 * \\
(0.098)\end{array}$ & $\begin{array}{l}0.214 * * \\
(0.096)\end{array}$ & $\begin{array}{c}0.100 \\
(0.076)\end{array}$ & $\begin{array}{c}0.253^{* * *} \\
(0.075)\end{array}$ & $\begin{array}{c}0.175^{* * *} \\
(0.052)\end{array}$ \\
\hline Capital to Working age population & $\begin{array}{c}-0.198^{* * *} \\
(0.031)\end{array}$ & $\begin{array}{c}0.144 * * * \\
(0.033)\end{array}$ & $\begin{array}{c}0.453^{* * *} \\
(0.041)\end{array}$ & $\begin{array}{c}0.413^{* * *} \\
(0.055)\end{array}$ & $\begin{array}{c}0.385 * * * \\
(0.057)\end{array}$ & $\begin{array}{c}0.379 * * * \\
(0.053)\end{array}$ & $\begin{array}{c}0.377 * * * \\
(0.050)\end{array}$ & $\begin{array}{c}0.318^{* * *} \\
(0.043)\end{array}$ & $\begin{array}{c}0.214^{* * *} \\
(0.032)\end{array}$ & $\begin{array}{c}0.027 \\
(0.020)\end{array}$ \\
\hline Urban population (\% of total) & $\begin{array}{c}-0.158 * * \\
(0.075)\end{array}$ & $\begin{array}{c}-0.064 \\
(0.088)\end{array}$ & $\begin{array}{c}-0.353 * * * \\
(0.085)\end{array}$ & $\begin{array}{c}-0.386^{* * *} \\
(0.095)\end{array}$ & $\begin{array}{c}-0.380 * * * \\
(0.098)\end{array}$ & $\begin{array}{c}-0.302^{* * *} \\
(0.093)\end{array}$ & $\begin{array}{c}-0.255^{* * *} \\
(0.092)\end{array}$ & $\begin{array}{l}-0.120 \\
(0.084)\end{array}$ & $\begin{array}{l}-0.023 \\
(0.074)\end{array}$ & $\begin{array}{c}0.068 \\
(0.069)\end{array}$ \\
\hline Average schooling years, male >15yrs & $\begin{array}{c}0.175 \\
(0.592)\end{array}$ & $\begin{array}{c}-1.612 * * \\
(0.665)\end{array}$ & $\begin{array}{c}-1.772 * * \\
(0.703)\end{array}$ & $\begin{array}{c}-2.052 * * * \\
(0.763)\end{array}$ & $\begin{array}{c}-1.901^{* *} \\
(0.816)\end{array}$ & $\begin{array}{c}-2.079 * * * \\
(0.795)\end{array}$ & $\begin{array}{c}-1.563 * * \\
(0.761)\end{array}$ & $\begin{array}{l}-1.127 \\
(0.701)\end{array}$ & $\begin{array}{l}-1.001 \\
(0.631)\end{array}$ & $\begin{array}{l}-0.917 * \\
(0.486)\end{array}$ \\
\hline Average schooling years, female $>15 y r s$ & $\begin{array}{c}0.360 \\
(0.713)\end{array}$ & $\begin{array}{c}2.942 * * * \\
(0.797)\end{array}$ & $\begin{array}{c}3.532 * * * \\
(0.908)\end{array}$ & $\begin{array}{c}3.942 * * * \\
(1.041)\end{array}$ & $\begin{array}{c}3.771 * * * \\
(1.074)\end{array}$ & $\begin{array}{c}3.520 * * * \\
(1.012)\end{array}$ & $\begin{array}{c}2.693 * * * \\
(0.942)\end{array}$ & $\begin{array}{l}1.967 * * \\
(0.878)\end{array}$ & $\begin{array}{l}1.814 * * \\
(0.764)\end{array}$ & $\begin{array}{l}1.512 * * \\
(0.606)\end{array}$ \\
\hline R-squared & 0.93 & 0.91 & 0.91 & 0.90 & 0.91 & 0.92 & 0.93 & 0.94 & 0.95 & 0.96 \\
\hline $\begin{array}{l}\text { Notes: } \\
\text { All regressions are based on a sample of } 770 \text { obse } \\
\text { Robust standard errors in parentheses. } \\
\text { * significant at } 10 \% \text {; }{ }^{* *} \text { significant at } 5 \% \text {; ** sig }\end{array}$ & ervations and i & nclude time dur & mmies and cou & Intry fixed effe & cts. & & & & & \\
\hline
\end{tabular}


Table 5: Female Labor Force Participation, Fixed Effects, 2SLS Estimation

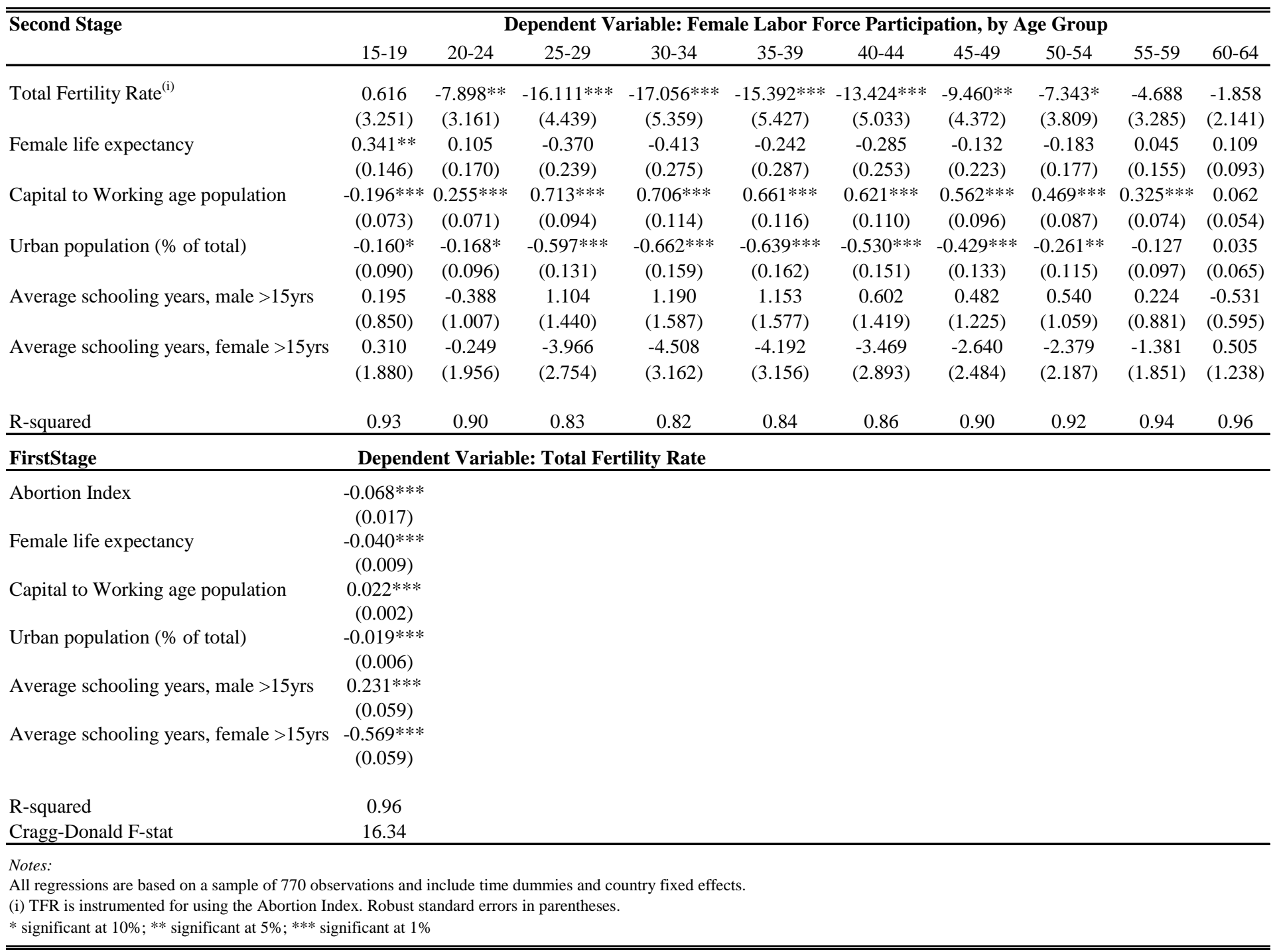


Table 6: Female Labor Force Participation, Fixed Effects, 2SLS Estimation, with country-specific time trend

\begin{tabular}{|c|c|c|c|c|c|c|c|c|c|c|}
\hline & \multicolumn{10}{|c|}{ Dependent Variable: Female Labor Force Participation, by Age Group } \\
\hline & $15-19$ & $20-24$ & $25-29$ & $30-34$ & 35-39 & $40-44$ & $45-49$ & $50-54$ & $55-59$ & $60-64$ \\
\hline Total Fertility Rate ${ }^{(\mathrm{i})}$ & $\begin{array}{c}1.373 \\
(3.732)\end{array}$ & $\begin{array}{l}-6.391 * \\
(3.366)\end{array}$ & $\begin{array}{l}-6.291 * \\
(3.269)\end{array}$ & $\begin{array}{c}-9.815^{* *} \\
(3.866)\end{array}$ & $\begin{array}{c}-12.454 * * * \\
(4.396)\end{array}$ & $\begin{array}{c}-10.530 * * \\
(4.138)\end{array}$ & $\begin{array}{l}-7.143^{*} \\
(3.738)\end{array}$ & $\begin{array}{l}-6.288 * \\
(3.445)\end{array}$ & $\begin{array}{l}-4.753 \\
(3.138)\end{array}$ & $\begin{array}{l}-4.120 \\
(2.651)\end{array}$ \\
\hline Female life expectancy & $\begin{array}{c}0.015 \\
(0.137)\end{array}$ & $\begin{array}{c}0.044 \\
(0.124)\end{array}$ & $\begin{array}{c}0.040 \\
(0.120)\end{array}$ & $\begin{array}{c}0.182 \\
(0.142)\end{array}$ & $\begin{array}{c}0.431^{* * *} \\
(0.162)\end{array}$ & $\begin{array}{c}0.205 \\
(0.152)\end{array}$ & $\begin{array}{c}0.289 * * \\
(0.138)\end{array}$ & $\begin{array}{c}0.189 \\
(0.127)\end{array}$ & $\begin{array}{c}0.328 * * * \\
(0.115)\end{array}$ & $\begin{array}{l}0.186^{*} \\
(0.098)\end{array}$ \\
\hline Capital to Working age population & $\begin{array}{l}-0.261 * \\
(0.147)\end{array}$ & $\begin{array}{c}0.038 \\
(0.133)\end{array}$ & $\begin{array}{c}0.294 * * \\
(0.129)\end{array}$ & $\begin{array}{c}0.368 * * \\
(0.153)\end{array}$ & $\begin{array}{c}0.423 * * \\
(0.173)\end{array}$ & $\begin{array}{c}0.402 * * \\
(0.163)\end{array}$ & $\begin{array}{c}0.369 * * \\
(0.147)\end{array}$ & $\begin{array}{c}0.369 * * * \\
(0.136)\end{array}$ & $\begin{array}{c}0.257 * * \\
(0.124)\end{array}$ & $\begin{array}{c}0.206 * * \\
(0.105)\end{array}$ \\
\hline Urban population (\% of total) & $\begin{array}{l}-0.123 \\
(0.162)\end{array}$ & $\begin{array}{l}-0.147 \\
(0.146)\end{array}$ & $\begin{array}{c}-0.387 * * * \\
(0.142)\end{array}$ & $\begin{array}{c}-0.387 * * \\
(0.168)\end{array}$ & $\begin{array}{c}-0.498 * * * \\
(0.191)\end{array}$ & $\begin{array}{c}-0.445^{* *} \\
(0.179)\end{array}$ & $\begin{array}{l}-0.254 \\
(0.162)\end{array}$ & $\begin{array}{l}-0.189 \\
(0.149)\end{array}$ & $\begin{array}{l}-0.122 \\
(0.136)\end{array}$ & $\begin{array}{l}-0.148 \\
(0.115)\end{array}$ \\
\hline Average schooling years, male $>15 y$ yrs & $\begin{array}{l}-0.683 \\
(1.151)\end{array}$ & $\begin{array}{c}0.924 \\
(1.038)\end{array}$ & $\begin{array}{c}0.491 \\
(1.008)\end{array}$ & $\begin{array}{c}1.596 \\
(1.193)\end{array}$ & $\begin{array}{l}2.319 * \\
(1.356)\end{array}$ & $\begin{array}{l}2.259 * \\
(1.277)\end{array}$ & $\begin{array}{l}2.015 * \\
(1.153)\end{array}$ & $\begin{array}{l}2.272 * * \\
(1.063)\end{array}$ & $\begin{array}{c}1.508 \\
(0.968)\end{array}$ & $\begin{array}{c}1.235 \\
(0.818)\end{array}$ \\
\hline Average schooling years, female $>15 y r s$ & $\begin{array}{c}0.214 \\
(1.675)\end{array}$ & $\begin{array}{l}-2.046 \\
(1.511)\end{array}$ & $\begin{array}{l}-1.531 \\
(1.467)\end{array}$ & $\begin{array}{c}-3.497 * * \\
(1.735)\end{array}$ & $\begin{array}{c}-4.539 * * \\
(1.973)\end{array}$ & $\begin{array}{c}-4.481^{* *} \\
(1.858)\end{array}$ & $\begin{array}{c}-3.771^{* *} \\
(1.678)\end{array}$ & $\begin{array}{c}-4.308 * * * \\
(1.546)\end{array}$ & $\begin{array}{c}-3.144^{* *} \\
(1.409)\end{array}$ & $\begin{array}{l}-1.992 * \\
(1.190)\end{array}$ \\
\hline Cragg-Donald F-stat & 8.26 & 8.26 & 8.26 & 8.26 & 8.26 & 8.26 & 8.26 & 8.26 & 8.26 & 8.26 \\
\hline R-squared & 0.97 & 0.98 & 0.98 & 0.98 & 0.97 & 0.98 & 0.98 & 0.98 & 0.99 & 0.99 \\
\hline
\end{tabular}

Notes:

All regressions are based on a sample of 770 observations and include time dummies, country fixed effects and country specific time trends.

(i) TFR is instrumented for using the Abortion Index. Robust standard errors in parentheses.

* significant at $10 \%$; ** significant at $5 \%$; ** significant at $1 \%$ 
Table 7: Female Labor Force Participation Fixed Effects, 2SLS Estimation with a Country Specific Trend and Lagged Female Labor Force Participation Rate

\begin{tabular}{|c|c|c|c|c|c|c|c|c|c|c|}
\hline & \multicolumn{10}{|c|}{ Dependent Variable: Female Labor Force Participation, by Age Group } \\
\hline & $15-19$ & $20-24$ & 25-29 & $30-34$ & 35-39 & $40-44$ & 45-49 & $50-54$ & $55-59$ & $60-64$ \\
\hline Total Fertility Rate ${ }^{(\mathrm{i})}$ & $\begin{array}{c}1.373 \\
(3.732)\end{array}$ & $\begin{array}{c}-7.779 * \\
(4.133)\end{array}$ & $\begin{array}{l}-3.227 \\
(4.228)\end{array}$ & $\begin{array}{c}-7.686 * \\
(3.975)\end{array}$ & $\begin{array}{c}-8.957 * * \\
(4.057)\end{array}$ & $\begin{array}{l}-5.008 \\
(3.533)\end{array}$ & $\begin{array}{c}-3.348 \\
(3.167)\end{array}$ & $\begin{array}{l}-3.185 \\
(3.094)\end{array}$ & $\begin{array}{c}-2.416 \\
(3.154)\end{array}$ & $\begin{array}{c}-1.826 \\
(2.759)\end{array}$ \\
\hline Lagged Participation & & $\begin{array}{c}0.262 * * * \\
(0.077)\end{array}$ & $\begin{array}{c}0.460 * * * \\
(0.113)\end{array}$ & $\begin{array}{c}0.497 * * * \\
(0.083)\end{array}$ & $\begin{array}{c}0.527 * * * \\
(0.065)\end{array}$ & $\begin{array}{c}0.581 * * * \\
(0.058)\end{array}$ & $\begin{array}{c}0.627 * * * \\
(0.046)\end{array}$ & $\begin{array}{c}0.529 * * * \\
(0.044)\end{array}$ & $\begin{array}{c}0.396 * * * \\
(0.046)\end{array}$ & $\begin{array}{c}\text { J.325*** } \\
(0.050)\end{array}$ \\
\hline Female life expectancy & $\begin{array}{c}0.015 \\
(0.137)\end{array}$ & $\begin{array}{c}0.029 \\
(0.129)\end{array}$ & $\begin{array}{c}-0.014 \\
(0.111)\end{array}$ & $\begin{array}{c}0.165 \\
(0.110)\end{array}$ & $\begin{array}{c}0.355^{* * *} \\
(0.118)\end{array}$ & $\begin{array}{c}0.016 \\
(0.108)\end{array}$ & $\begin{array}{c}0.230 * * \\
(0.095)\end{array}$ & $\begin{array}{c}0.089 \\
(0.097)\end{array}$ & $\begin{array}{c}0.267 * * * \\
(0.099)\end{array}$ & $\begin{array}{c}0.097 \\
(0.087)\end{array}$ \\
\hline Capital to Working age population & $\begin{array}{c}-0.261^{*} \\
(0.147)\end{array}$ & $\begin{array}{c}0.104 \\
(0.135)\end{array}$ & $\begin{array}{c}0.182 \\
(0.133)\end{array}$ & $\begin{array}{c}0.201 \\
(0.141)\end{array}$ & $\begin{array}{c}0.210 \\
(0.144)\end{array}$ & $\begin{array}{c}0.154 \\
(0.123)\end{array}$ & $\begin{array}{c}0.138 \\
(0.115)\end{array}$ & $\begin{array}{c}0.178 \\
(0.114)\end{array}$ & $\begin{array}{c}0.097 \\
(0.117)\end{array}$ & $\begin{array}{c}0.077 \\
(0.103)\end{array}$ \\
\hline Urban population (\% of total) & $\begin{array}{c}-0.123 \\
(0.162)\end{array}$ & $\begin{array}{c}-0.216 \\
(0.195)\end{array}$ & $\begin{array}{c}-0.316 \\
(0.196)\end{array}$ & $\begin{array}{c}-0.242 \\
(0.202)\end{array}$ & $\begin{array}{c}-0.411^{* *} \\
(0.193)\end{array}$ & $\begin{array}{l}-0.236 \\
(0.168)\end{array}$ & $\begin{array}{l}-0.099 \\
(0.151)\end{array}$ & $\begin{array}{c}-0.134 \\
(0.145)\end{array}$ & $\begin{array}{c}-0.140 \\
(0.146)\end{array}$ & $\begin{array}{c}-0.184 \\
(0.125)\end{array}$ \\
\hline Average schooling years, male $>15 y r s$ & $\begin{array}{l}-0.683 \\
(1.151)\end{array}$ & $\begin{array}{c}1.223 \\
(1.062)\end{array}$ & $\begin{array}{c}-0.183 \\
(1.023)\end{array}$ & $\begin{array}{c}0.728 \\
(1.043)\end{array}$ & $\begin{array}{c}0.702 \\
(1.103)\end{array}$ & $\begin{array}{l}-0.004 \\
(0.971)\end{array}$ & $\begin{array}{c}0.050 \\
(0.884)\end{array}$ & $\begin{array}{c}0.454 \\
(0.870)\end{array}$ & $\begin{array}{c}0.212 \\
(0.894)\end{array}$ & $\begin{array}{c}0.376 \\
(0.772)\end{array}$ \\
\hline Average schooling years, female $>15 y r s$ & $\begin{array}{c}0.214 \\
(1.675)\end{array}$ & $\begin{array}{l}-2.049 \\
(1.525)\end{array}$ & $\begin{array}{c}-0.007 \\
(1.495)\end{array}$ & $\begin{array}{c}-1.612 \\
(1.483)\end{array}$ & $\begin{array}{l}-1.455 \\
(1.564)\end{array}$ & $\begin{array}{c}-0.526 \\
(1.373)\end{array}$ & $\begin{array}{c}-0.491 \\
(1.237)\end{array}$ & $\begin{array}{l}-1.330 \\
(1.216)\end{array}$ & $\begin{array}{c}-1.019 \\
(1.248)\end{array}$ & $\begin{array}{c}-0.576 \\
(1.088)\end{array}$ \\
\hline Cragg-Donald F-stat & 8.26 & 5.96 & 4.53 & 5.71 & 5.76 & 5.53 & 6.40 & 6.62 & 6.75 & 6.12 \\
\hline R-squared & 0.97 & 0.98 & 0.99 & 0.99 & 0.99 & 0.99 & 0.99 & 0.99 & 0.99 & 0.99 \\
\hline Number of Observations & 770 & 673 & 673 & 673 & 673 & 673 & 673 & 673 & 673 & 673 \\
\hline
\end{tabular}

Notes:

All regressions are based on a sample of 770 observations and include time dummies, country fixed effects and country specific time trends.

(i) TFR is instrumented for using the Abortion Index. Robust standard errors in parentheses.

* significant at $10 \%$; ** significant at $5 \%$; *** significant at $1 \%$ 
Table 8: Female Labor Force Participation 2SLS Estimation: First-Stage Results (country-specific time trend and lag)

\begin{tabular}{|c|c|c|c|c|c|c|c|c|c|c|}
\hline \multirow{2}{*}{$\begin{array}{l}\text { First Stage } \\
\text { Age Group }\end{array}$} & \multicolumn{10}{|c|}{ Dependent Variable: Total Fertility Rate } \\
\hline & $15-19$ & $20-24$ & $25-29$ & $30-34$ & $35-39$ & $40-44$ & $45-49$ & $50-54$ & $55-59$ & $60-64$ \\
\hline Abortion Index & $\begin{array}{c}-0.045^{* * *} \\
(0.016)\end{array}$ & $\begin{array}{c}-0.036 * * \\
(0.015)\end{array}$ & $\begin{array}{c}-0.031 * * \\
(0.014)\end{array}$ & $\begin{array}{c}-0.035^{* *} \\
(0.015)\end{array}$ & $\begin{array}{c}-0.036^{* *} \\
(0.015)\end{array}$ & $\begin{array}{c}-0.035^{* *} \\
(0.015)\end{array}$ & $\begin{array}{c}-0.038 * * \\
(0.015)\end{array}$ & $\begin{array}{c}-0.039 * * \\
(0.015)\end{array}$ & $\begin{array}{c}-0.039 * * * \\
(0.015)\end{array}$ & $\begin{array}{c}-0.037 * * \\
(0.015)\end{array}$ \\
\hline Lagged Participation & & $\begin{array}{c}-0.016 * * * \\
(0.004)\end{array}$ & $\begin{array}{c}-0.025 * * * \\
(0.004)\end{array}$ & $\begin{array}{c}-0.018 * * * \\
(0.004)\end{array}$ & $\begin{array}{c}-0.012 * * * \\
(0.004)\end{array}$ & $\begin{array}{c}-0.013 * * * \\
(0.004)\end{array}$ & $\begin{array}{c}-0.010 * * \\
(0.004)\end{array}$ & $\begin{array}{l}-0.008^{*} \\
(0.004)\end{array}$ & $\begin{array}{l}-0.008^{*} \\
(0.005)\end{array}$ & $\begin{array}{c}-0.012 * * \\
(0.005)\end{array}$ \\
\hline Female life expectancy & $\begin{array}{c}0.029 * * * \\
(0.007)\end{array}$ & $\begin{array}{c}0.025^{* * *} \\
(0.007)\end{array}$ & $\begin{array}{c}0.021^{* * *} \\
(0.007)\end{array}$ & $\begin{array}{c}0.021^{* * *} \\
(0.007)\end{array}$ & $\begin{array}{c}0.023^{* * *} \\
(0.007)\end{array}$ & $\begin{array}{c}0.025^{* * *} \\
(0.007)\end{array}$ & $\begin{array}{c}0.023^{* * *} \\
(0.007)\end{array}$ & $\begin{array}{c}0.024^{* * *} \\
(0.007)\end{array}$ & $\begin{array}{c}0.024^{* * *} \\
(0.007)\end{array}$ & $\begin{array}{c}0.025^{* * *} \\
(0.007)\end{array}$ \\
\hline Capital to Working age population & $\begin{array}{c}0.035^{* * *} \\
(0.004)\end{array}$ & $\begin{array}{c}0.029 * * * \\
(0.004)\end{array}$ & $\begin{array}{c}0.029 * * * \\
(0.004)\end{array}$ & $\begin{array}{c}0.032^{* * *} \\
(0.004)\end{array}$ & $\begin{array}{c}0.032^{* * * *} \\
(0.004)\end{array}$ & $\begin{array}{c}0.032 * * * \\
(0.004)\end{array}$ & $\begin{array}{c}0.033^{* * *} \\
(0.004)\end{array}$ & $\begin{array}{c}0.033^{* * *} \\
(0.004)\end{array}$ & $\begin{array}{c}0.033^{* * *} \\
(0.004)\end{array}$ & $\begin{array}{c}0.034^{* * *} \\
(0.005)\end{array}$ \\
\hline Urban population (\% of total) & $\begin{array}{c}-0.036 * * * \\
(0.007)\end{array}$ & $\begin{array}{c}-0.041^{* * *} \\
(0.008)\end{array}$ & $\begin{array}{c}-0.042 * * * \\
(0.008)\end{array}$ & $\begin{array}{c}-0.045 * * * \\
(0.008)\end{array}$ & $\begin{array}{c}-0.042 * * * \\
(0.008)\end{array}$ & $\begin{array}{c}-0.042 * * * \\
(0.008)\end{array}$ & $\begin{array}{c}-0.041 * * * \\
(0.008)\end{array}$ & $\begin{array}{c}-0.040 * * * \\
(0.008)\end{array}$ & $\begin{array}{c}-0.039 * * * \\
(0.008)\end{array}$ & $\begin{array}{c}-0.039 * * * \\
(0.008)\end{array}$ \\
\hline Average schooling years, male $>15 y r s$ & $\begin{array}{c}0.262 * * * \\
(0.053)\end{array}$ & $\begin{array}{c}0.222^{* * *} \\
(0.050)\end{array}$ & $\begin{array}{c}0.216^{* * *} \\
(0.049)\end{array}$ & $\begin{array}{c}0.230 * * * \\
(0.050)\end{array}$ & $\begin{array}{c}0.239 * * * \\
(0.051)\end{array}$ & $\begin{array}{c}0.243^{* * *} \\
(0.051)\end{array}$ & $\begin{array}{c}0.243 * * * \\
(0.051)\end{array}$ & $\begin{array}{c}0.243^{* * *} \\
(0.051)\end{array}$ & $\begin{array}{c}0.245^{* * *} \\
(0.052)\end{array}$ & $\begin{array}{c}0.245^{* * *} \\
(0.051)\end{array}$ \\
\hline Average schooling years, female $>15 y r s$ & $\begin{array}{c}-0.415^{* * * *} \\
(0.058)\end{array}$ & $\begin{array}{c}-0.339 * * * \\
(0.057)\end{array}$ & $\begin{array}{c}-0.331 * * * \\
(0.055)\end{array}$ & $\begin{array}{c}-0.345 * * * \\
(0.057)\end{array}$ & $\begin{array}{c}-0.357 * * * \\
(0.057)\end{array}$ & $\begin{array}{c}-0.361 * * * \\
(0.057)\end{array}$ & $\begin{array}{c}-0.358 * * * \\
(0.058)\end{array}$ & $\begin{array}{c}-0.359 * * * \\
(0.058)\end{array}$ & $\begin{array}{c}-0.361 * * * \\
(0.058)\end{array}$ & $\begin{array}{c}-0.362^{* * *} \\
(0.058)\end{array}$ \\
\hline Observations & 770 & 673 & 673 & 673 & 673 & 673 & 673 & 673 & 673 & 673 \\
\hline R-squared & 0.99 & 0.99 & 0.99 & 0.99 & 0.99 & 0.99 & 0.99 & 0.99 & 0.99 & 0.99 \\
\hline
\end{tabular}

Notes:

All regressions are based on a sample of 770 observations and include time dummies, country fixed effects and country specific time trends.

Robust standard errors in parentheses.

* significant at $10 \%$; ** significant at $5 \%$; ** significant at $1 \%$ 
Figure 1: Income per Capita and Female Labor Force Participation 2000

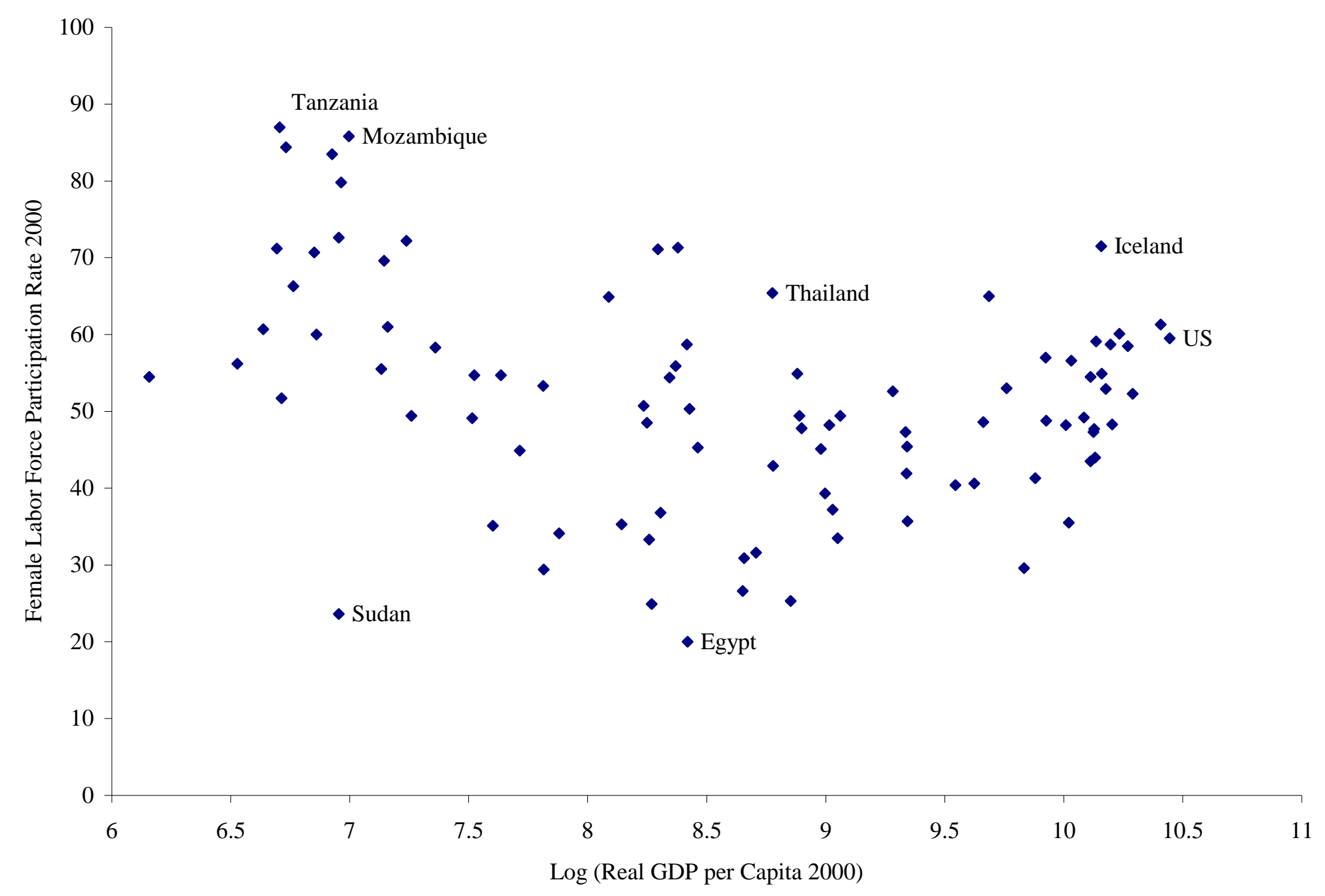


Figure 2: Income per Capita 1980 and Change in Female Labor Force Participation 1980-2000

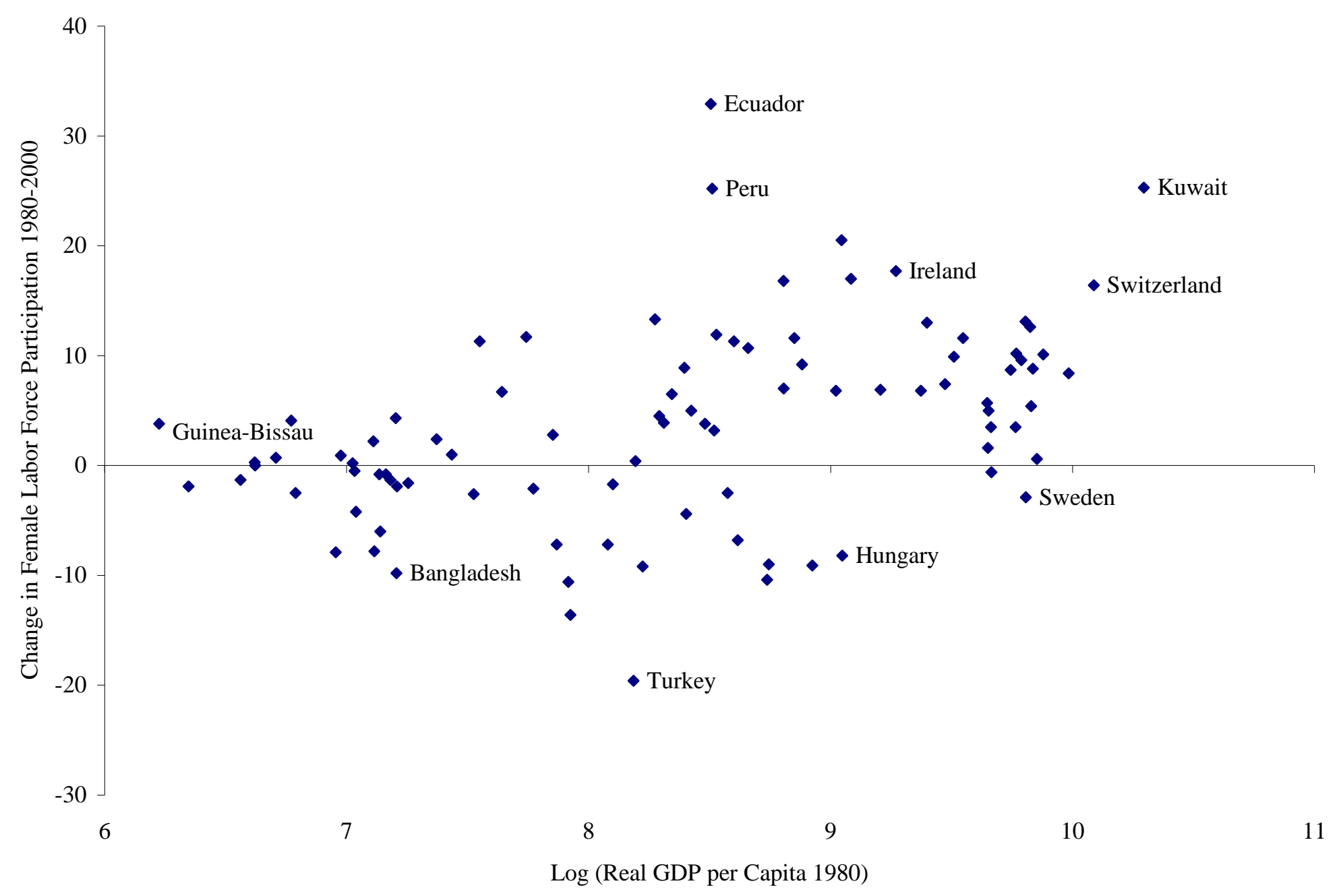


Figure 3: Direct and Cumulative Effect of Fertility on Female Labor Force Participation

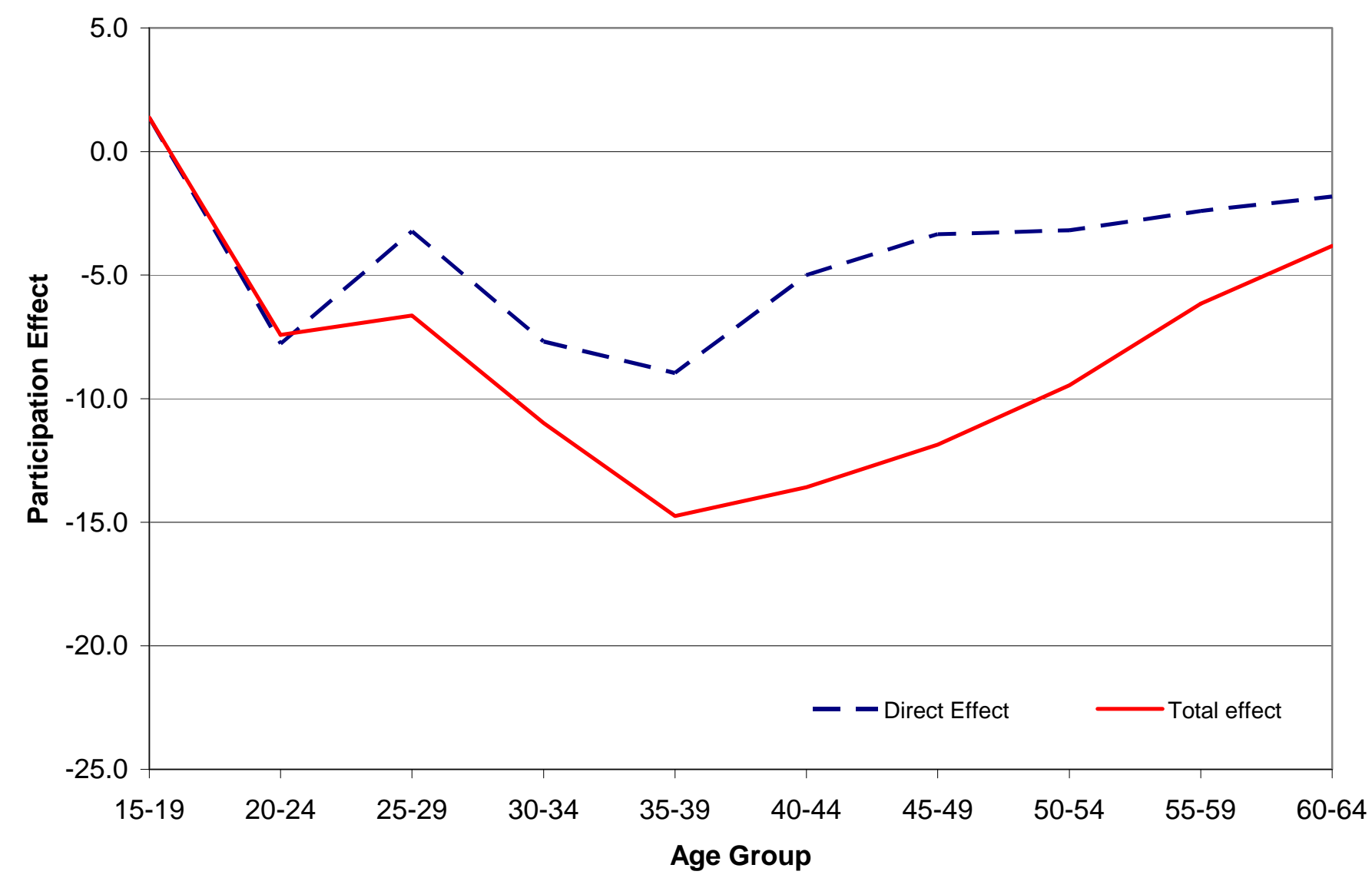

Note: This graph corresponds to the results presented in Table 7. 
Figure 4: South Korea, Total Fertility Rates and Female Labor Market Participation 1960-2000

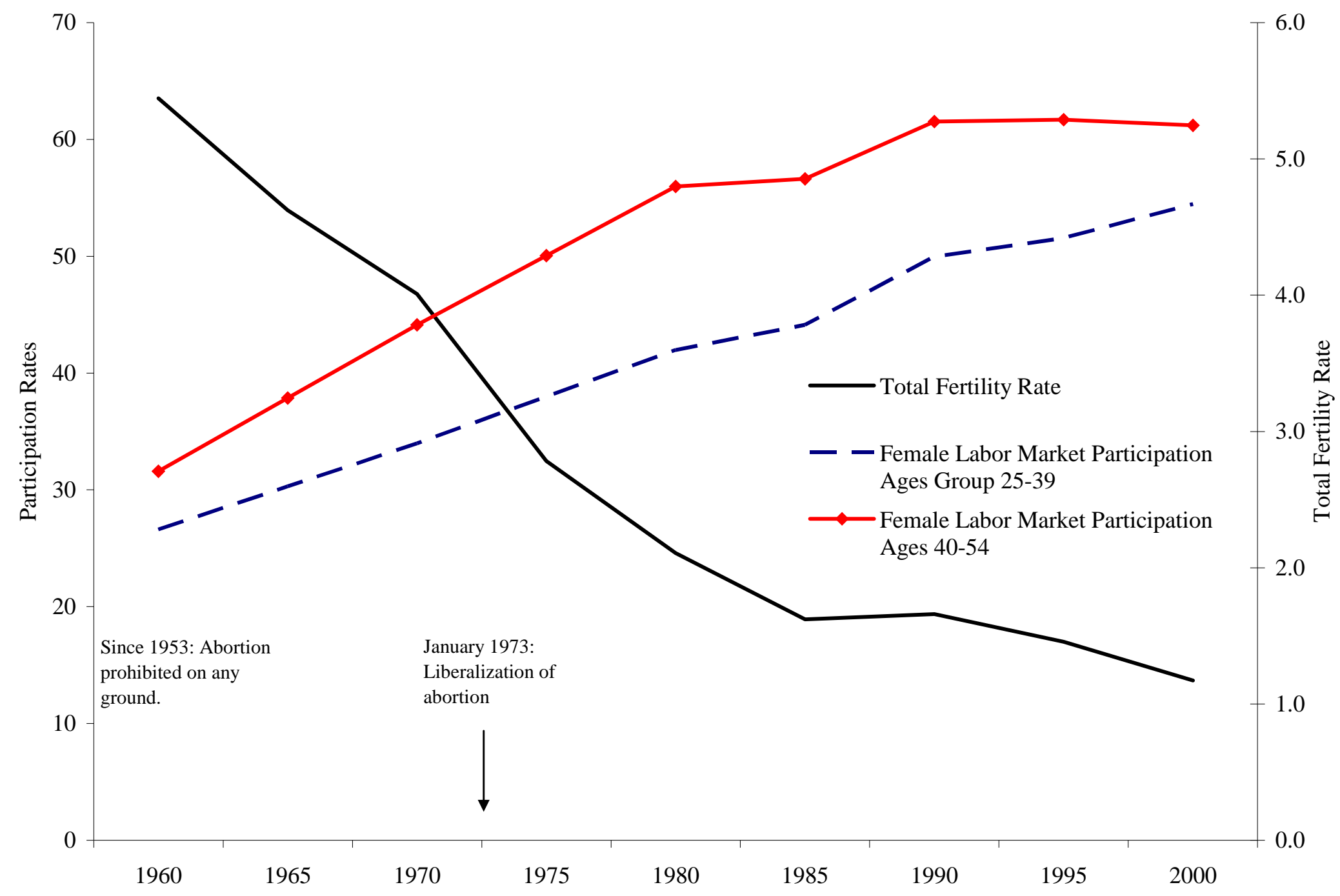


Figure 5: Simulation of the Economic Consequences of Fertility Reduction in South Korea (1960 Participation Rates, and Constant 1960 Life Expectancy)

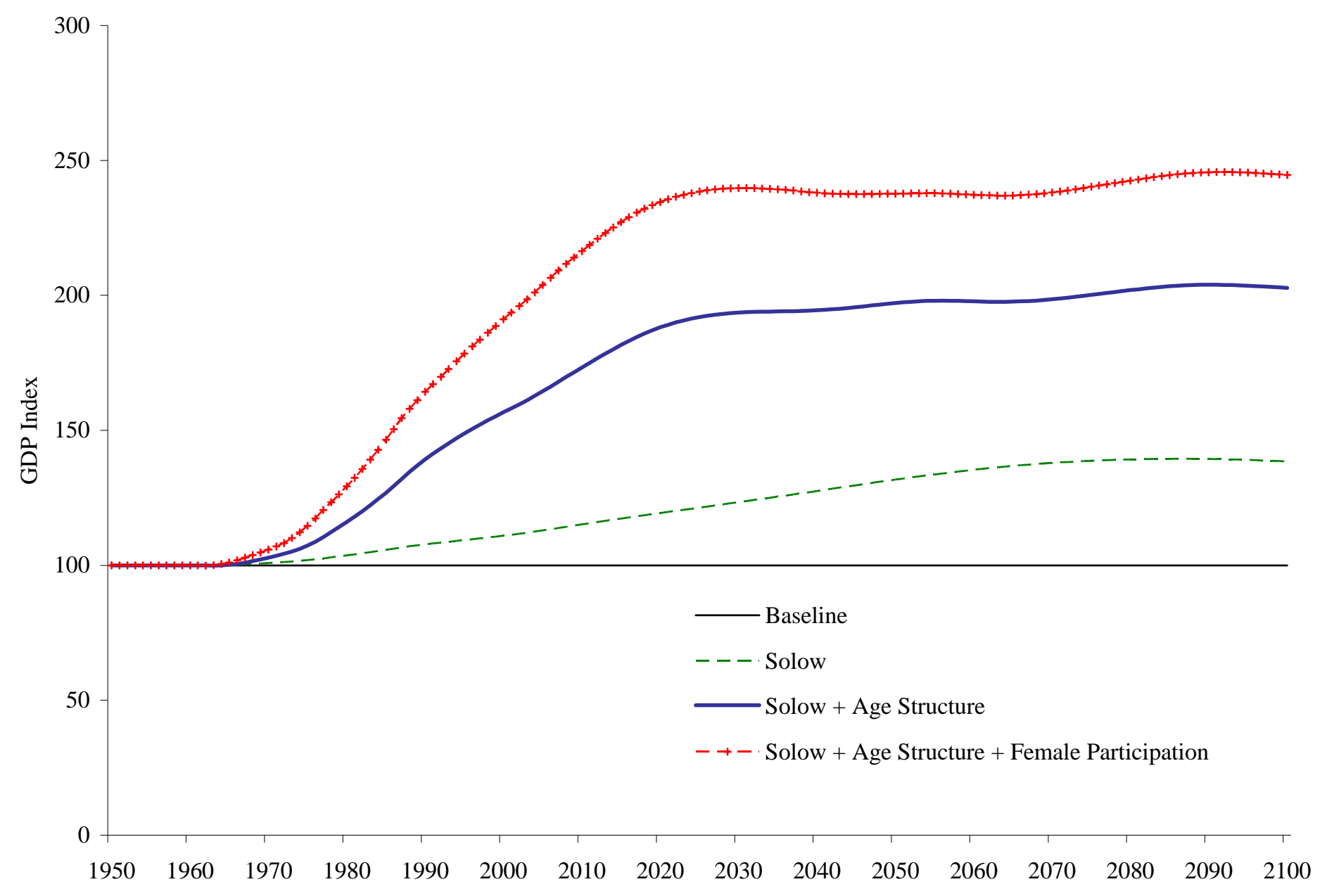




\section{Appendix}

Table A1: Variable Description

\begin{tabular}{|c|c|}
\hline $\begin{array}{l}\text { Age-Group-Specific } \\
\text { Female Labor Force } \\
\text { Participation }\end{array}$ & $\begin{array}{l}\text { The labor force participation rate is the number of women in the } \\
\text { labor force in a given age group divided by the female } \\
\text { population of the same age group. Labor force participation data } \\
\text { are from the International Labor Organization (ILO 1997; ILO } \\
\text { Bureau of Statistics 2007). The data from 1960-1980 and from } \\
\text { 1980-2000 are taken from two different data sets. To ensure } \\
\text { continuity in the data we take the growth of participation from } \\
\text { 1960-1980 in one data set and extrapolate back from the } 1980 \\
\text { participation rate in the 1980-2000 dataset. }\end{array}$ \\
\hline $\begin{array}{l}\text { Lagged Female Labor } \\
\text { Force Participation }\end{array}$ & $\begin{array}{l}\text { The participation rate of the cohort of interest in period t-5. For } \\
\text { example, the lagged participation of } 25-29 \text { year old females in } \\
2000 \text {, is the participation of the } 20-24 \text { year olds in } 1995 \text {. For } \\
\text { data source see Age Group Specific Female Labor Participation } \\
\text { (ILO 1997; ILO Bureau of Statistics 2007). }\end{array}$ \\
\hline Fertility (TFR) & $\begin{array}{l}\text { The total fertility rate is the average number of children that } \\
\text { would be born to a woman over her fertile life if she were to } \\
\text { experience the current age-specific fertility rate through these } \\
\text { years. The data are taken from the World Development } \\
\text { Indicators (World Bank 2006). For the missing survey years } \\
1965 \text { and } 1975 \text {, we take the linear averages of } 1962 \text { and 1967, } \\
\text { and } 1972 \text { and } 1977 \text { survey values, respectively. }\end{array}$ \\
\hline Female Life Expectancy & $\begin{array}{l}\text { Defined as female life expectancy at birth. Data are from the } \\
\text { World Development Indicators (World Bank 2006) and linearly } \\
\text { interpolated between survey years. }\end{array}$ \\
\hline $\begin{array}{l}\text { Capital per working-age } \\
\text { population }\end{array}$ & $\begin{array}{l}\text { Total capital stock in } 2004 \text { US\$ PPP from the Penn World } \\
\text { Tables } 6.2 \text { (Heston et. al., 2006) divided by the population in the } \\
\text { age groups } 15 \text { to } 64 \text {. Population data come from the World } \\
\text { Population Prospects (United Nations 2004). }\end{array}$ \\
\hline Urban Population & $\begin{array}{l}\text { Percent of the total population living in an urban area. Source: } \\
\text { World Development Indicators (World Bank 2006). }\end{array}$ \\
\hline $\begin{array}{l}\text { Average years of schooling } \\
\text { in the female/male } \\
\text { population }>15\end{array}$ & $\begin{array}{l}\text { The average years of schooling among females and males above } \\
\text { the age of fifteen. Source: Barro and Lee (2000). }\end{array}$ \\
\hline Abortion Index & $\begin{array}{l}\text { Abortion Index is the sum of the } 7 \text { abortion law indicator } \\
\text { variables. In each abortion law category - life threatening, } \\
\text { physical health of the mother, mental health of the mother, rape, } \\
\text { fetal impairment, economic, request - a one indicates that an } \\
\text { abortion is legally available for the classified reason and a zero } \\
\text { that it is not. The Abortion Index ranges from zero, which } \\
\text { indicates that abortion is not legal under any classification, and } \\
\text { seven, which means that an abortion is available for all of the } \\
\text { seven reasons. Data Source: United Nations Population Division } \\
\text { (2002). }\end{array}$ \\
\hline
\end{tabular}


Table A2: Country List

\begin{tabular}{lll}
\hline \hline 1 Afghanistan & 34 Guinea-Bissau & 67 Panama \\
2 Algeria & 35 Haiti & 68 Papua New Guinea \\
3 Argentina & 36 Honduras & 69 Peru \\
4 Australia & 37 Hungary & 70 Philippines \\
5 Austria & 38 Iceland & 71 Poland \\
6 Bahrain & 39 India & 72 Portugal \\
7 Bangladesh & 40 Indonesia & 73 Rwanda \\
8 Barbados & 41 Iran, Islamic Rep. & 74 Senegal \\
9 Belgium & 42 Iraq & 75 Sierra Leone \\
10 Benin & 43 Ireland & 76 Singapore \\
11 Botswana & 44 Israel & 77 South Africa \\
12 Brazil & 45 Italy & 78 Spain \\
13 Cameroon & 46 Jamaica & 79 Sri Lanka \\
14 Canada & 47 Japan & 80 Sudan \\
15 Central African Republic & 48 Jordan & 81 Swaziland \\
16 Chile & 49 Kenya & 82 Sweden \\
17 China & 50 Korea, Rep. & 83 Switzerland \\
18 Colombia & 51 Kuwait & 84 Syrian Arab Republic \\
19 Congo, Rep. & 52 Lesotho & 85 Tanzania \\
20 Costa Rica & 53 Liberia & 86 Thailand \\
21 Cyprus & 54 Malawi & 87 Togo \\
22 Denmark & 55 Malaysia & 88 Trinidad and Tobago \\
23 Dominican Republic & 56 Mali & 89 Tunisia \\
24 Ecuador & 57 Mauritius & 90 Turkey \\
25 Egypt, Arab Rep. & 58 Mexico & 91 Uganda \\
26 El Salvador & 59 Mozambique & 92 United Kingdom \\
27 Fiji & 60 Nepal & 93 United States \\
28 Finland & 61 Netherlands & 94 Uruguay \\
29 France & 62 New Zealand & 95 Venezuela, RB \\
30 Gambia, The & 63 Nicaragua & 96 Zambia \\
31 Ghana & 64 Niger & 97 Zimbabwe \\
32 Greece & 65 Norway & \\
33 Guatemala & 66 Pakistan & \\
\hline \hline
\end{tabular}




\section{Appendix A}

We have

$$
\begin{aligned}
& \frac{\partial^{2} V}{\partial n^{2}}=-\frac{k+\beta}{n^{2}}-\frac{\alpha b^{2}}{(1-l-b n-\varepsilon)^{2}}<0 \\
& \frac{\partial^{2} V}{\partial l^{2}}=-\frac{w^{2}}{\left(w l+c_{0}\right)^{2}}-\frac{\alpha}{(1-l-b n-\varepsilon)^{2}}<0 \\
& \frac{d^{2} V}{d l^{2}} \frac{d^{2} V}{d n^{2}}-\left(\frac{d^{2} V}{d n d l}\right)^{2}=\frac{(k+\beta) w^{2}}{n^{2}\left(l w+c_{0}\right)^{2}}+\frac{\alpha(k+\beta)}{n^{2}(1-l-b n-\varepsilon)^{2}}+\frac{\alpha b^{2} w^{2}}{(1-l-b n-\varepsilon)^{2}\left(w l+c_{0}\right)^{2}}>0 .
\end{aligned}
$$

Hence the Hessian matrix of $2^{\text {nd }}$ derivatives is negative semi-definite and the first-order conditions give a local maximum. 